\title{
Study of Cathode Materials for Lithium-Ion Batteries: Recent Progress and New Challenges
}

\author{
Florian Schipper ${ }^{1}$, Prasant Kumar Nayak ${ }^{1}$, Evan M. Erickson ${ }^{1}$, S. Francis Amalraj ${ }^{1}$, \\ Onit Srur-Lavi ${ }^{1}$, Tirupathi Rao Penki ${ }^{1}$, Michael Talianker ${ }^{2}$, Judith Grinblat ${ }^{1}$, Hadar Sclar ${ }^{1}$, \\ Ortal Breuer ${ }^{1}$, Christian M. Julien ${ }^{3}$, Nookala Munichandraiah ${ }^{4}$, Daniela Kovacheva ${ }^{5}$, \\ Mudit Dixit ${ }^{1}$, Dan Thomas Major ${ }^{1}$, Boris Markovsky ${ }^{1}$ and Doron Aurbach ${ }^{1, *}$ \\ 1 Department of Chemistry, Bar-Ilan University, Ramat Gan 5290002, Israel; schippf@biu.ac.il (F.S.); \\ prasantnayak15@gmail.com (P.K.N.); evan.erikson@biu.ac.il (E.M.E.); sfamalraj@gmail.com (S.F.A.); \\ onit.srlavi@gmail.com (O.S.-L.); tiru.penki@gmail.com (T.R.P.); judith.grinblat@biu.ac.il (J.G.); \\ hadar.sclar@biu.ac.il (H.S.); ortalik150@gmail.com (O.B.); dixitmuditk@gmail.com (M.D.); \\ dan-thomas.major@biu.ac.il (D.T.M.); boris.markovsky@biu.ac.il (B.M.) \\ 2 Department of Materials Engineering, Ben-Gurion University of the Negev, Beer Sheva 84105, Israel; \\ mtalianker973@gmail.com \\ 3 Sorbonne Universités, UPMC Univ. Paris 6, Physicochimie des Electrolytes et Nanosystèmes \\ Interfaciaux (PHENIX), UMR 8234, 75005 Paris, France; christian.julien@courriel.upmc.fr \\ 4 Department of Inorganic and Physical Chemistry, Indian Institute of Science, Bangalore 560012, India; \\ muni@ipc.iisc.ernet.in \\ 5 Institute of General and Inorganic Chemistry, Bulgarian Academy of Sciences, Sofia 1113, Bulgaria; \\ didka@svr.igic.bas.bg \\ * Correspondence: doron.aurbach@biu.ac.il; Tel.: +972-3-531-83-17
}

Academic Editor: Venkataraman Thangadurai

Received: 5 March 2017; Accepted: 20 April 2017; Published: 28 April 2017

\begin{abstract}
Amongst a number of different cathode materials, the layered nickel-rich $\mathrm{LiNi}_{y} \mathrm{Co}_{x} \mathrm{Mn}_{1-y-x} \mathrm{O}_{2}$ and the integrated lithium-rich $x \mathrm{Li}_{2} \mathrm{MnO}_{3} \cdot(1-x) \mathrm{Li}\left[\mathrm{Ni}_{a} \mathrm{Co}_{b} \mathrm{Mn}_{c}\right] \mathrm{O}_{2}(a+b+c=1)$ have received considerable attention over the last decade due to their high capacities of $\sim 195$ and $\sim 250 \mathrm{mAh} \cdot \mathrm{g}^{-1}$, respectively. Both materials are believed to play a vital role in the development of future electric vehicles, which makes them highly attractive for researchers from academia and industry alike. The review at hand deals with both cathode materials and highlights recent achievements to enhance capacity stability, voltage stability, and rate capability, etc. The focus of this paper is on novel strategies and established methods such as coatings and dopings.
\end{abstract}

Keywords: lithium ion batteries; cathode; Li-rich; Ni-rich; review

\section{Introduction}

Li-ion batteries (LIBs) are high-energy-density power sources, and their development since the 1980s-1990s can be considered one of the most important successes of modern electrochemistry. It is a fact that in the past decades, LIBs have conquered the market of portable electronic devices such as cellular phones, tape-recorders, cameras, etc. Because of their reliability and general excellent performance at various temperatures, cycling behavior, stability and safety, LIBs are beginning to be used for highly demanding applications, such as electric vehicles (EVs). This is due, first of all, to their high energy density and good cyclability [1-4]. Important materials for cathodes (or positive electrodes) of LIBs are lithium and manganese-rich layered composites from the $x \mathrm{Li}_{2} \mathrm{MnO}_{3} \cdot(1-x) \mathrm{Li}\left[\mathrm{Ni}_{a} \mathrm{Co}_{b} \mathrm{Mn}_{c}\right] \mathrm{O}_{2}(a+b+c=1)$ family that are normally described as comprising two layered structure phases, $\mathrm{Li}_{2} \mathrm{MnO}_{3}(C / 2 m$ space group) and $\mathrm{Li}\left[\mathrm{Ni}_{a} \mathrm{Co}_{b} \mathrm{Mn}_{c}\right] \mathrm{O}_{2}(a+b+c=1)(R \overline{3} m$ space group $)$, integrated on the atomic level [5-8]. These two 
layered, structurally compatible nano-domains exist side by side in the composite materials. The $x \mathrm{Li}_{2} \mathrm{MnO}_{3} \cdot(1-x) \mathrm{Li}\left[\mathrm{Ni}_{a} \mathrm{Co}_{b} \mathrm{Mn}_{c}\right] \mathrm{O}_{2}$ materials in Li-cells, mentioned above, deliver high discharge capacities in excess of $250 \mathrm{mAh} / \mathrm{g}[9,10]$. A recent paper by Dahn et al. describes them as a single $C 2 / m$ phase of $\mathrm{Li}_{1+y} \mathrm{Ni}_{a} \mathrm{Co}_{b} \mathrm{Mn}_{c} \mathrm{O}_{2}(y+a+b+c=1)$ [11-13]. However, other researchers suggest a multi-phase structure, referring to electron diffraction data showing the presence of both $C 2 / m$ and $R \overline{3} m$ components as well as X-ray-diffraction peaks with different intensity ratios for the two phases $[9,14-16]$.

Another group of cathode materials for LIBs is lithiated transition-metal (TM) oxides comprising $\mathrm{Ni}, \mathrm{Co}$ and $\mathrm{Mn}$, of the general formula $\mathrm{LiNi}_{y} \mathrm{Co}_{x} \mathrm{Mn}_{1-y-x} \mathrm{O}_{2}$. These materials have attracted much attention since their first synthesis by Liu et al. in 1999 [17]. The symmetric structure $\mathrm{LiNi}_{1 / 3} \mathrm{Co}_{1 / 3} \mathrm{Mn}_{1 / 3} \mathrm{O}_{2}$ (denoted NCM 333) was studied by Ohzuku, and demonstrated a capacity of $200 \mathrm{mAh} / \mathrm{g}$ within the voltage range of 2.5-4.6 V [18,19], or $\sim 155 \mathrm{mAh} / \mathrm{g}$ if the anodic voltage is limited by $4.3 \mathrm{~V}$ [20]. Such materials with higher Ni content $(y>5)$ are important as well, due to the high capacity that can be extracted by charging up to $4.3 \mathrm{~V}$ only. Hence, there are two families of cathode materials that are considered the most important, $\mathrm{Li}$ - and Mn-rich $x \mathrm{Li}_{2} \mathrm{MnO}_{3} \cdot(1-x) \mathrm{Li}\left[\mathrm{Ni}_{a} \mathrm{Co}_{b} \mathrm{Mn}_{c}\right] \mathrm{O}_{2}$ and Ni-rich $(y>0.5) \mathrm{LiNi}_{y} \mathrm{Co}_{x} \mathrm{Mn}_{1-y-x} \mathrm{O}_{2}$, having their own advantages and drawbacks as cathodes in LIBs. These materials have attracted considerable attention from experts in solid-state chemistry, materials science and electrochemistry, as well as from industrial companies, as promising candidates in LIBs for EV-application.

In this review, we discuss the recent progress and challenges of the cathode materials mentioned above, with an emphasis on their modification by lattice doping and thin surface coatings. These modifications result in substantial improvement in the electrode performance, decreased capacity fading and stabilization of the average voltage during cycling, mitigation of side reactions with solution species and an increase in the thermal stability in charged states.

\section{Lithium- and Manganese-Rich Layered Structure Materials}

Electrodes comprising $\mathrm{Li}$ - and $\mathrm{Mn}$-rich materials require an activation step by charging to more than $4.5 \mathrm{~V}$ during the first cycle to reach high capacities [21-24]. The charge profile in Figure 1A, measured during the first cycle, demonstrates assignments of $\mathrm{Li}^{+}$intercalation sites and redox centers made by in situ X-ray-diffraction measurements (XRD) and X-ray-absorption spectroscopy (XAS), respectively [10,14,25-28]. Upon initial charging of $\mathrm{Li}-$ and Mn-rich materials, $\mathrm{Ni}^{2+/ 4+}$ and $\mathrm{Co}^{3+/ 4+}$ oxidation occurs, as in standard $\mathrm{Li}\left[\mathrm{Ni}_{a} \mathrm{Co}_{b} \mathrm{Mn}_{c}\right] \mathrm{O}_{2}$ layered materials [10,14]. Afterwards, a long activation voltage plateau at about $4.5 \mathrm{~V}$ appears, involving $\mathrm{O}_{2}$ evolution, formation of a surface spinel phase and $\mathrm{Li}^{+}$extraction from the TM-layer [14,29-32]. At higher potentials, anionic oxidation of $\mathrm{O}^{2-}$ takes place, recently discovered by several groups [33-36] to occur with concomitant TM migration to the Li-layer between the $\mathrm{O}^{2-}$ slabs left unshielded after excessive $\mathrm{Li}^{+}$extraction [10,14]. This migration of transition metals to the Li-layer causes resistance towards $\mathrm{Li}^{+}$re-intercalation and a large voltage hysteresis between charge and discharge [37-40]. Upon discharge, depicted by the differential capacity plot in Figure $1 \mathrm{~B}, \mathrm{Li}^{+}$first enters the TM-layer with $\mathrm{O}^{2-x}, \mathrm{Ni}^{4+}$ and $\mathrm{Co}^{4+}$, and with $\mathrm{Mn}^{4+}$ reduction, followed by $\mathrm{Li}^{+}$intercalation into the Li-layer with further $\mathrm{Mn}^{4+}$ reduction $[10,14]$. 

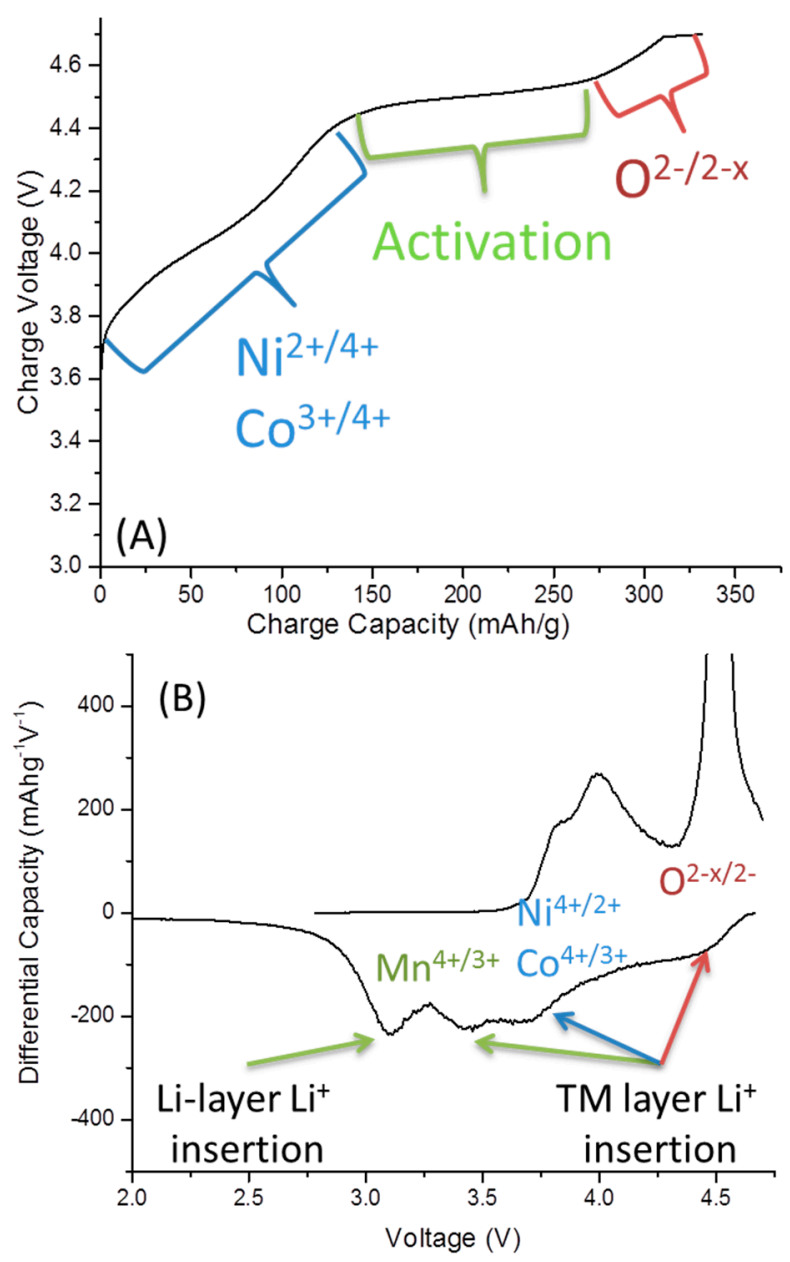

Figure 1. (A) Charge and (B) $\mathrm{d} Q / \mathrm{d} V$ profiles for the first cycle of a representative Li-rich $0.35 \mathrm{LiMn}{ }_{2} \mathrm{O}_{3} \cdot 0.65 \mathrm{Li}\left[\mathrm{Mn}_{0.45} \mathrm{Ni}_{0.35} \mathrm{Co}_{0.20}\right] \mathrm{O}_{2}$ electrode in a $\mathrm{Li}$-cell at a rate of $\mathrm{C} / 20,30{ }^{\circ} \mathrm{C}$. Modified from [41].

The TM migration to the Li-layer during later stages of charging, that causes the large charge/discharge voltage hysteresis, is also the main reason for the large capacity fades during the cycling of the Li- and Mn-rich materials [37-40].

The intense capacity and voltage fade associated with $\mathrm{Li}$ - and $\mathrm{Mn}$-rich materials is highlighted in Figure $\mathrm{S} 1$ in the Supporting Information, in comparison with a Ni-rich $\mathrm{LiNi}_{0.8} \mathrm{Co}_{0.1} \mathrm{Mn}_{0.1} \mathrm{O}_{2}$ cathode as an example [41,42]. While both materials suffer from discharge capacity decay (Figure S1A), the voltage fade is especially problematic for the Li- and Mn-rich materials (Figure S1B) [41,42]. Here, the dramatic effect of the voltage hysteresis of these materials, caused by TM-migration, is evident; a difference of $\sim 0.4 \mathrm{~V}$ in the average voltage is observed, as well as a large fade over cycling.

As described above, the electrochemically inactive monoclinic phase $\mathrm{Li}_{2} \mathrm{MnO}_{3}$ is converted into an electrochemically active component by suitable integration at the molecular level with another component, which possesses inherent electrochemical activity. The Li-Mn-O system is promising for the further enhancement of the specific capacity of the cathode material and, hence, the energy density of the Li-ion cells. Recently, a $\mathrm{Li}-\mathrm{Mn}-\mathrm{O}$ system of nominal composition, " $\mathrm{Li}_{4} \mathrm{Mn}_{2} \mathrm{O}_{5}$ ", was reported as a novel cathode material with a specific capacity exceeding $300 \mathrm{~mA} \cdot \mathrm{h} / \mathrm{g}$ by an $\mathrm{Mn}^{3+} / \mathrm{Mn}^{5+}$ two-electron redox process, as was confirmed by magnetic measurements [43]. The oxide is prepared by a mechano-chemical route at ambient temperature using orthorhombic $\mathrm{LiMnO}_{2}$ and $\mathrm{Li}_{2} \mathrm{O}$ with a 2:1 molar ratio. The electrodes made of $\mathrm{Li}_{4} \mathrm{Mn}_{2} \mathrm{O}_{5}$ are subjected to galvanostatic charge/discharge cycling at a rate of $\mathrm{C} / 20$ by gradually increasing the upper voltage limit from 4.4 to $4.6 \mathrm{~V}$, and then 
to $4.8 \mathrm{~V}$. Under these conditions, the sample is completely charged by removing four $\mathrm{Li}^{+}$ions per formula unit. The reversible capacity measured is $355 \mathrm{~mA} \cdot \mathrm{h} / \mathrm{g}$ (equivalent to $2.88 \mathrm{Li}^{+}$per formula unit). It is the highest capacity reported until now among the known $\mathrm{Li}-\mathrm{Mn}-\mathrm{O}$ electrode materials. The electrochemical activity is attributed to the $\mathrm{Mn}^{3+} / \mathrm{Mn}^{4+}, \mathrm{Mn}^{4+} / \mathrm{Mn}^{5+}$ and $\mathrm{O}^{2-} / \mathrm{O}^{-}$redox couples. The mechanism is supported by magnetic measurements.

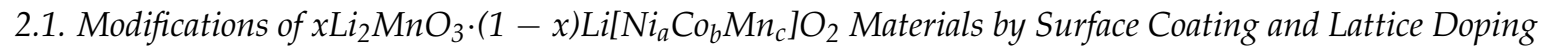

The general consensus in the field of Li-ion batteries is that functional surface coatings and the modification of electrodes by lattice doping may play a critical role in improving their electrochemical properties, cycle life and thermal behavior. $\mathrm{A}$ wide variety of materials was investigated for use as coatings, including the metal oxides $\mathrm{SnO}, \mathrm{Al}_{2} \mathrm{O}_{3}, \mathrm{TiO}_{2}, \mathrm{MgO}$ and $\mathrm{ZrO}_{2}$ [44-47], fluorides such as $\mathrm{AlF}_{3}$ and $\mathrm{ZrF}_{x}$ [48,49], and phosphates such as $\mathrm{AlPO}_{4}$ [50]. Recently, we studied the structural characteristics and electrochemical behavior of electrodes comprising $\mathrm{Li}$ - and $\mathrm{Mn}$-rich $\mathrm{Li}_{x}[\mathrm{MnNiCo}] \mathrm{O}_{2}$ cathode materials (prepared at BASF, Ludwigshafen, Germany) with the stoichiometry of $x \mathrm{Li}_{2} \mathrm{MnO}_{3} \cdot(1$ $-x) \mathrm{LiMn}_{y} \mathrm{Ni}_{z} \mathrm{Co}_{w} \mathrm{O}_{2}$ at $60^{\circ} \mathrm{C}(x$ is in the range $0.4-0.5$, and the $y: z: w$ ratio was already reported, coated with $\mathrm{AlF}_{3}$ (about 2-3 wt \%)) [16]. Special emphasis was given to the possible structural transformation during the activation and cycling of these electrodes, to solution and interfacial reactions, and to the stability of the $\mathrm{AlF}_{3}$ coating during prolonged charge/discharge cycling at $60{ }^{\circ} \mathrm{C}$. We also studied possible interactions between the aluminum fluoride and the core of the active material, to better understand the effect of this coating on all the chemical, electrochemical and thermal processes of the electrodes. For the purpose of conducting Rietveld analysis and in keeping with previous studies, we confirm that the structure of the $x \mathrm{Li}_{2} \mathrm{MnO}_{3} \cdot(1-x) \mathrm{Li}\left[\mathrm{Mn}_{y} \mathrm{Ni}_{z} \mathrm{Co}_{w}\right] \mathrm{O}_{2}$ pristine material is composed of two structurally compatible constituents: the monoclinic component $\mathrm{Li}_{2} \mathrm{MnO}_{3}$ (space group $\mathrm{C} 2 / \mathrm{m}$ ) and the rhombohedral component $\mathrm{LiMO}_{2}$ (space group $\left.R \overline{3} m\right)(M=\mathrm{Mn}, \mathrm{Ni}, \mathrm{Co})$. These two layered $\mathrm{Li}_{2} \mathrm{MnO}_{3}$ and $\mathrm{Li} M \mathrm{O}_{2}$ nanodomains exist side by side in the structure. From the Rietveld refinement for the $x \mathrm{Li}_{2} \mathrm{MnO}_{3} \cdot(1-x) \mathrm{Li}\left[\mathrm{Mn}_{y} \mathrm{Ni}_{z} \mathrm{Co}_{w}\right] \mathrm{O}_{2}$ pristine material coated with $\mathrm{AlF}_{3}$, the Bragg R-factors for the rhombohedral and monoclinic phases were calculated and found to be 0.046 and 0.082 , respectively. The refined cell parameters for $\mathrm{Li}_{2} \mathrm{MnO}_{3}$ were: $a=4.945(0) \AA, b=8.594(0) \AA, c=5.023(09) \AA$ and $\beta=108.86$; and for $\mathrm{Li}(\mathrm{Ni}, \mathrm{Co}, \mathrm{Mn}) \mathrm{O}_{2}: a=2.855(4) \AA$ and $c=14.251(1) \AA$.

The additional structural information about the $x \mathrm{Li}_{2} \mathrm{MnO}_{3} \cdot(1-x) \mathrm{Li}\left[\mathrm{Mn}_{y} \mathrm{Ni}_{z} \mathrm{Co}_{w}\right] \mathrm{O}_{2}$ pristine material coated with $\mathrm{AlF}_{3}$ used here was obtained by TEM studies (Figure 2). Using the dark-field imaging technique in $\mathrm{TEM}$, it was possible to infer that the $\mathrm{AlF}_{3}$ coating layer consists of extremely small (5-8 nm) $\mathrm{AlF}_{3}$ crystalline nanoparticles uniformly distributed over the particle surface. $\mathrm{The}^{-\mathrm{AlF}_{3}}$ coating appears as thin crystalline layers covering the particle surface, indicated by arrows in the inset (c). 


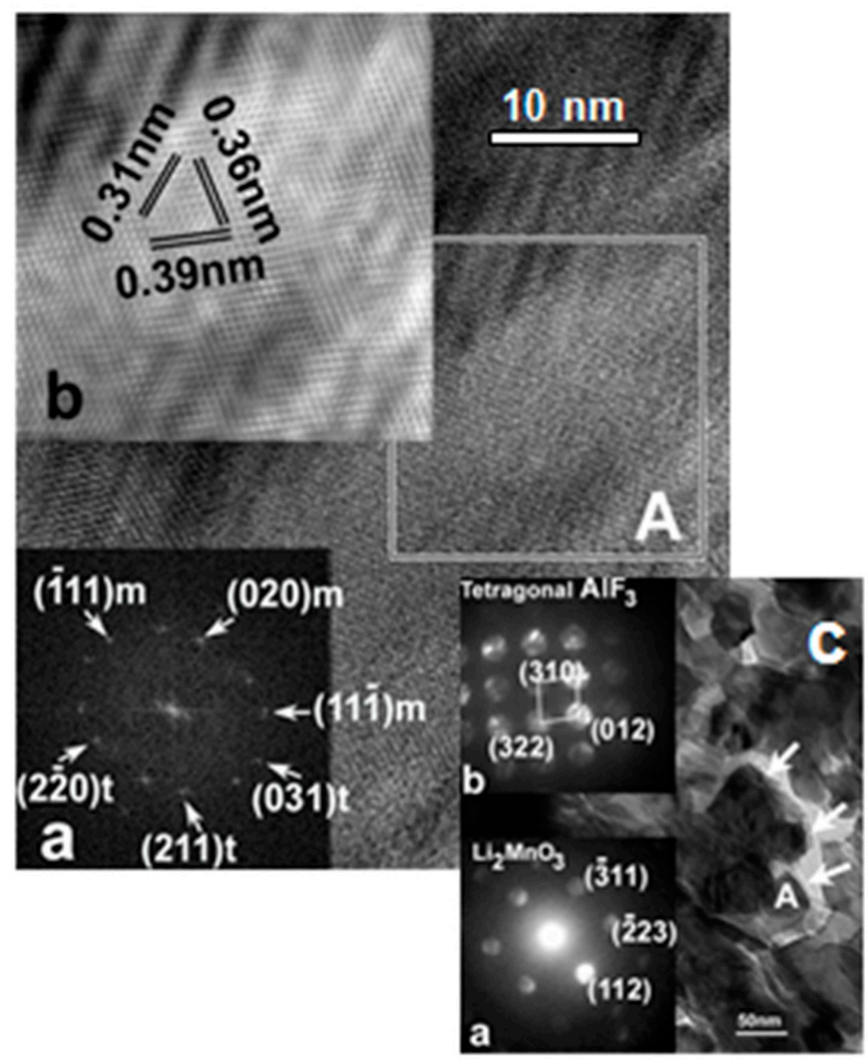

Figure 2. HRTEM image of the $x \mathrm{Li}_{2} \mathrm{MnO}_{3} \cdot(1-x) \mathrm{Li}\left[\mathrm{Mn}_{y} \mathrm{Ni}_{z} \mathrm{Co}_{\mathrm{w}}\right] \mathrm{O}_{2}(x$ around $0.5, y: z: w$ around 2:2:1) pristine material coated with $\mathrm{AlF}_{3}$. Inset $(\mathbf{a})$ is the Fourier transform of the image in a square marked by A. Subscripts $(\mathrm{m})$ and $(\mathrm{t})$ of the indexed spots are related to the monoclinic $\mathrm{Li}_{2} \mathrm{MnO}_{3}$ and tetragonal $\mathrm{t}-\mathrm{AlF}_{3}$ phases, respectively; Inset $(\mathbf{b})$ shows a filtered image of the $\mathrm{AlF}_{3}$ coating layer; Inset (a) exhibits a superposition of two sets of reflection spots, $\mathrm{Li}_{2} \mathrm{MnO}_{3}$ and $\mathrm{t}-\mathrm{AlF}_{3}$; Inset (b) demonstrates a filtered image of the $\mathrm{AlF}_{3}$ structure with distances of $0.36,0.39$ and $0.31 \mathrm{~nm}$ between lattice fringes, which match the interplanar spacing $d_{220}, d_{211}$ and $d_{301}$ in the $t-A_{1 F}$ phase, respectively; Inset (c) is a TEM micrograph showing the microstructure of the $\mathrm{xLi}_{2} \mathrm{MnO}_{3} \cdot(1-x) \mathrm{Li}\left[\mathrm{Mn}_{y} \mathrm{Ni}_{z} \mathrm{Co}_{w}\right] \mathrm{O}_{2}$ pristine material coated with $\mathrm{AlF}_{3}$. CBED patterns (a) and (b) are indexed on the basis of the monoclinic $\mathrm{Li}_{2} \mathrm{MnO}_{3}$ and tetragonal $\mathrm{AlF}_{3}$ structures, respectively. The layers of $\mathrm{AlF}_{3}$ are indicated by arrows. The coating crystallizes into the tetragonal structure $\mathrm{t}-\mathrm{AlF}_{3}$ described by the $P 4 n m m$ symmetry, possessing a unit cell with the parameters $a=10.1843 \AA$ and $c=7.1738 \AA$. Reprinted from [16].

We have previously shown that $x \mathrm{Li}_{2} \mathrm{MnO}_{3} \cdot(1-x) \mathrm{Li}\left[\mathrm{Mn}_{y} \mathrm{Ni}_{z} \mathrm{Co}_{w}\right] \mathrm{O}_{2}(x$ around $0.5, y: z: w$ around 2:2:1) electrodes can be effectively cycled at both 30 and $60{ }^{\circ} \mathrm{C}$, with reversible capacities of about 220-250 $\mathrm{mAh} \cdot \mathrm{g}^{-1}$ at a rate of $\mathrm{C} / 5$ [16]. The $\mathrm{AlF}_{3}$-coated electrodes also exhibit stable charge/discharge behavior, providing higher capacities and lower fade upon prolonged cycling at $60{ }^{\circ} \mathrm{C}$ (Figure $\left.3 \mathrm{~A}, \mathrm{~B}\right)$. It has recently been established that the $\mathrm{AlF}_{3}$ coating ( $>3 \mathrm{wt} \%$ ) may interact with the layered cathode material $\left(\mathrm{Li}_{2} \mathrm{MnO}_{3}\right)$, leading to partial extraction ("leaching") of the Li-ions from it and the formation of a spinel-like structure [51]. We suggest that the uniformly distributed nano-sized $\mathrm{AlF}_{3}$ possesses high surface area and may indeed act as a strong Lewis acid in reactions with the lithiated TM-oxide, resulting in partial irreversible delithiation even in the pristine (initial) state [52]. During the first charge of $\mathrm{Li}_{2} \mathrm{MnO}_{3}$-containing electrodes, charge compensation during the extraction of lithium occurs, involving both oxygen removal from the $\mathrm{Li}_{2} \mathrm{MnO}_{3}$ structure and an exchange between $\mathrm{Li}^{+}$and $\mathrm{H}^{+}$in the solutions, according to the formulas [53]:

$$
2 \mathrm{O}^{2-} \text { (lattice) } \rightarrow \mathrm{O}_{2} \text { (gas) }+4 \mathrm{e}^{-}
$$




$$
\mathrm{Li}_{2} \mathrm{MnO}_{3}+\mathrm{H}^{+} \rightarrow \mathrm{LiHMnO}_{3}+\mathrm{Li}^{+}
$$

Lithium carbonate is always formed in the air on TM-oxide electrodes, and its formation involves irreversible delithiation, according to:

$$
\mathrm{Li}_{2} \mathrm{MnO}_{3}+x \mathrm{CO}_{2} \rightarrow \mathrm{Li}_{2-2 x} \mathrm{MnO}_{3-x}+x \mathrm{Li}_{2} \mathrm{CO}_{3}
$$

Surface lithium carbonate can be replaced by $\mathrm{LiF}$ according to the reaction in the battery solution containing $\mathrm{LiPF}_{6}$ and unavoidably present free $\mathrm{HF}$, according to:

$$
\mathrm{Li}_{2} \mathrm{CO}_{3}+2 \mathrm{HF}_{\text {sol }} \rightarrow 2 \mathrm{LiF}+\mathrm{H}_{2} \mathrm{O}+\mathrm{CO}_{2}
$$

We assume that $\mathrm{AlF}_{3}$ substitutes the highly resistive $\mathrm{LiF}$ species and develops $\mathrm{LiAlF}_{4}$ (or $\left.\mathrm{Li}_{1-x} \mathrm{AlF}_{3+x}\right)$ at the interface, which may play an important role in the enhancement of the $\mathrm{Li}$ transport processes due to its exclusively high ionic conductivity, around $10^{-6}-10^{-4} \mathrm{~S} \cdot \mathrm{cm}^{-1}$ at room temperature [54]. Along with $\mathrm{Li}_{1-x} \mathrm{AlF}_{3+x}$, some other species, such as an $\mathrm{Al}-\mathrm{F}-\mathrm{O}-\mathrm{H}$-type species, can also be formed on the active material coated with $\mathrm{AlF}_{3}$, as has been demonstrated by TEM studies. Therefore, we suggest that the higher reversible capacities of the $\mathrm{AlF}_{3}$-coated electrodes may relate to the enhanced $\mathrm{Li}^{+}$-ion transport properties at the interface that comprises the species mentioned above, since these species also promote lower impedance and more uniform and fast intercalation/deintercalation processes. For instance, at a rate of $C / 3$, uncoated and coated materials provide $\sim 210$ and $\sim 260 \mathrm{mAh} \cdot \mathrm{g}^{-1}$, respectively. We have established that the mean charge voltage for the uncoated and $\mathrm{AlF}_{3}$-coated electrodes is almost invariant as a function of cycling, and is $\sim 500 \mathrm{mV}$ lower for the coated electrodes (Figure 3C). This can be attributed to the more energetically favorable $\mathrm{Li}^{+}$-ion extraction from the $\mathrm{AlF}_{3}$-coated electrodes and to the lower impedance of these electrodes developed upon cycling. At the same time, the mean voltage in discharge decreases continuously with cycling to $\sim 3.1 \mathrm{~V}$ for both electrodes. This change in discharge voltage obviously reflects gradual structural changes in the active mass, such as the gradual development of spinel-like structural ordering, as reflected by TEM measurements. We found that during cycling at $60^{\circ} \mathrm{C}$, the impedance of the $\mathrm{AlF}_{3}$-coated electrodes is indeed smaller than that of the uncoated electrodes.

Comparing the XRD patterns of the cycled electrode (at $60^{\circ} \mathrm{C}$ ) with those of the pristine electrode clearly reveals the appearance of the peaks of a spinel $\mathrm{LiMn}_{2} \mathrm{O}_{4}$-like phase (Figure S2). It is clear, therefore, that the layered components of the integrated electrode material partially convert to a spinel-like phase upon cycling, in agreement with previously reported observations of layered-to-spinel-type structural transformation induced by electrochemical cycling [55-57]. The Raman spectra of the cycled $x \mathrm{Li}_{2} \mathrm{MnO}_{3} \cdot(1-x) \mathrm{Li}\left[\mathrm{Mn}_{y} \mathrm{Ni}_{z} \mathrm{Co}_{w}\right] \mathrm{O}_{2}$ electrodes are characterized by broader main peaks and a lower ratio of intensities, attributable to some structural disordering and increased conductivity, respectively, compared to the pristine electrodes. These spectra reveal the formation of spinel-type ordering, reflected by the blue-shift of the $A_{1 g}$ mode at $\sim 600 \mathrm{~cm}^{-1}$ in the pristine electrodes to $\sim 625 \mathrm{~cm}^{-1}$ in cycled material, implying partial transformation of the layered structure. 

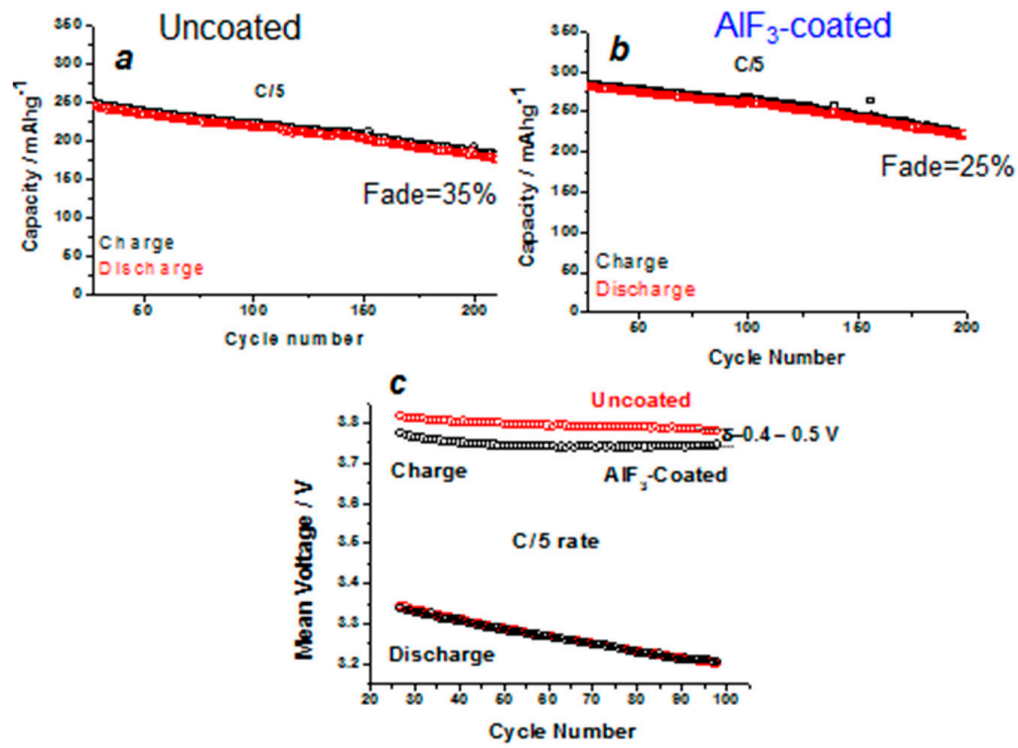

Figure 3. Charge/discharge cycling behavior at $60{ }^{\circ} \mathrm{C}$ of the uncoated $x \mathrm{Li}_{2} \mathrm{MnO}_{3} \cdot(1-x) \mathrm{Li}\left[\mathrm{Mn}_{y} \mathrm{Ni}_{z} \mathrm{Co}_{w}\right] \mathrm{O}_{2}$ ( $x$ around 0.5, y:z:w around 2:2:1) electrode (a) and of a similar electrode comprising $\mathrm{AlF}_{3}$ coated material (b); Mean voltage of these electrodes registered in charge and in discharge as a function of cycle number (c). Reprinted from [16].

Figure 4 (charts $\mathrm{A}$ and $\mathrm{B}$ ) demonstrates the differential scanning calorimetry (DSC) responses of the $x \mathrm{Li}_{2} \mathrm{MnO}_{3} \cdot(1-x) \mathrm{Li}\left[\mathrm{Mn}_{y} \mathrm{Ni}_{z} \mathrm{Co}_{w}\right] \mathrm{O}_{2}$ (uncoated and $\mathrm{AlF}_{3}$-coated) materials in contact with the EC-DMC $/ 1 \mathrm{M} \mathrm{LiPF}_{6}$ solution at $40-400{ }^{\circ} \mathrm{C}$. It was found that the thermal decomposition of the solution alone exhibits an exothermic peak at $243{ }^{\circ} \mathrm{C}$. The calculated heat of this reaction is about $400 \mathrm{~J} / \mathrm{g}$. The DSC response of $\mathrm{xLi}_{2} \mathrm{MnO}_{3} \cdot(1-x) \mathrm{Li}\left[\mathrm{Mn}_{y} \mathrm{Ni}_{z} \mathrm{Co}_{w}\right] \mathrm{O}_{2}$ with the EC-DMC $/ 1 \mathrm{M} \mathrm{LiPF} 6$ solution does not demonstrate the thermal decomposition peak of the electrolyte solution. However, at least three exothermic peaks appear, starting at $215^{\circ} \mathrm{C}$, and they are accompanied by a total heat evolution of $440 \mathrm{~J} \cdot \mathrm{g}^{-1}$. The observed exothermic peaks are related to the well-known pronounced thermal reactions between lithiated transition-metal-oxide cathode material and solution species (curve $b$ ). Surface modification of $\mathrm{xLi}_{2} \mathrm{MnO}_{3} \cdot(1-x) \mathrm{Li}\left[\mathrm{Mn}_{y} \mathrm{Ni}_{z} \mathrm{Co}_{w}\right] \mathrm{O}_{2}$ with aluminum fluoride significantly enhances the thermal stability, shifting the onset of the thermal reactions to higher temperatures and lowering the total specific heat of the reactions by more than $10 \%$ (curve $c$ ). We suggest that the $\mathrm{AlF}_{3}$ coating significantly reduces the direct contact area between the active mass and the solution species. Since the electrochemical or chemical delithiation of the monoclinic component $\mathrm{Li}_{2} \mathrm{MnO}_{3}$ of the cathode material is accompanied by oxygen evolution, this oxygen can react with $\mathrm{AlF}_{3}$ to form $\mathrm{Al}_{2} \mathrm{O}_{3}$ at $200{ }^{\circ} \mathrm{C}$ [58]. Supposedly, alumina thus formed does not sufficiently protect the surface of the material at elevated temperatures, and the interfacial reactions may accelerate to more than $200^{\circ} \mathrm{C}$. Indeed, the DSC measurements detect an onset of very slow exothermic reactions at $220^{\circ} \mathrm{C}$, which is about $20^{\circ} \mathrm{C}$ higher than the temperature of the uncoated material. The strong exothermic peak appears at $260^{\circ} \mathrm{C}, 45^{\circ} \mathrm{C}$ above the temperature of the uncoated material. The DSC response obtained from the uncoated $x \mathrm{Li}_{2} \mathrm{MnO}_{3} \cdot(1-x) \mathrm{Li}\left[\mathrm{Mn}_{y} \mathrm{Ni}_{z} \mathrm{Co}_{w}\right] \mathrm{O}_{2}$ active mass after the 20th charge (delithiated state at $60^{\circ} \mathrm{C}$ ) shows three well-resolved exothermic peaks (curve $d$ ). The exothermic peak observed with the cycled electrode is $198^{\circ} \mathrm{C}$, accompanied by a specific heat release of $\sim 1015 \mathrm{~J} \cdot \mathrm{g}^{-1}$, while the DSC response of the charged $\mathrm{AlF}_{3}$-coated cathode material (delithiated state at $60^{\circ} \mathrm{C}$ ) after $20 \mathrm{cycles}$ (Figure 4 chart B) differs significantly from that of the pristine state. The thermal stability decreases and the temperature of the main exothermic reaction is shifted to $\sim 236^{\circ} \mathrm{C}$. The ratio between the exothermic peaks changes and the heat release increases more than twofold. Such differences may be related to the surface and bulk changes of the cathode material upon cycling, and the results obtained correlate well with previous reports [58-61]. To summarize, the surface modification by $\mathrm{AlF}_{3}$ coating of these 
Li- and Mn-rich cathode materials improves their thermal stability in pristine and delithiated states compared to the uncoated electrodes. These results are in line with the TEM data, demonstrating that even after cycling at $60{ }^{\circ} \mathrm{C}$, the $\mathrm{AlF}_{3}$ coating still remains stable on the surface of the cathode material.

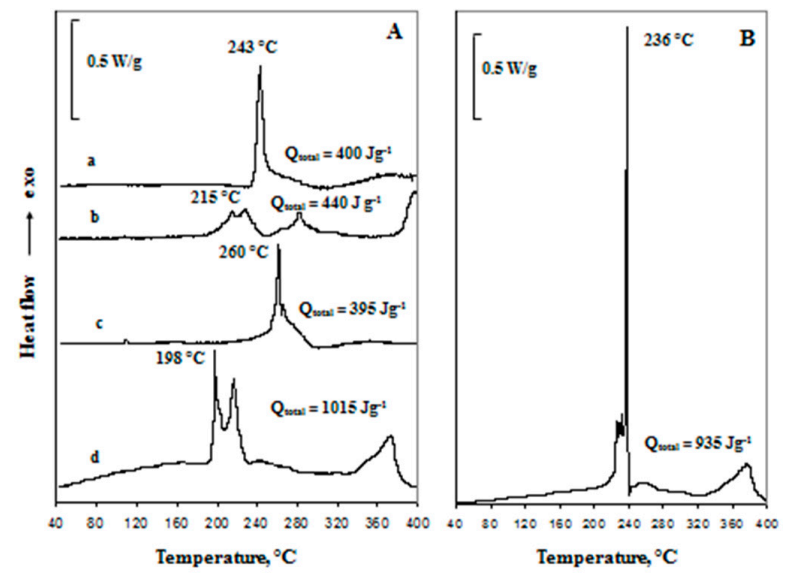

Figure 4. Typical DSC responses measured upon heating. In chart (A) (a) $1 \mathrm{M} \mathrm{LiPF}_{6} / \mathrm{EC}: \mathrm{DMC} 1: 1$ electrolyte solution, $(b-d)$ uncoated and $\mathrm{AlF}_{3}$-coated $x \mathrm{Li}_{2} \mathrm{MnO}_{3} \cdot(1-x) \mathrm{Li}\left[\mathrm{Mn}_{y} \mathrm{Ni}_{z} \mathrm{Co}_{w}\right] \mathrm{O}_{2}(x$ around $0.5, y: z: w$ around 2:2:1) materials in the same solution: $(b)$ pristine uncoated electrode, (c) pristine $\mathrm{AlF}_{3}$-coated electrode, $(d)$ uncoated charged electrode (delithiated state) after 20th cycle at $60{ }^{\circ} \mathrm{C}$. In chart (B) $\mathrm{AlF}_{3}$-coated charged electrode (delithiated state) after 20th cycle at $60{ }^{\circ} \mathrm{C}$. Reprinted from [16].

Novel hybrid materials composed of $\mathrm{Mg}^{2+}$ and $\mathrm{LiMgPO}_{4}$ have been proposed by Liu et al [62] As protective surface layers on $\mathrm{Li}$ - and $\mathrm{Mn}$-rich $\mathrm{Li}_{1.17} \mathrm{Ni}_{0.17} \mathrm{Co}_{0.17} \mathrm{Mn}_{0.5} \mathrm{O}_{2}$ material in order to lessen the capacity fading and voltage decay during prolonged cycling at 24 and $60^{\circ} \mathrm{C}$. Figure 5 shows a schematic illustration of surface-coated cathode material with hybrid $\mathrm{LiMgPO}_{4}$ material and preparation of the surface-modified $\mathrm{Li}_{1.17} \mathrm{~N}_{0.17} \mathrm{C}_{0.17} \mathrm{Mn}_{0.5} \mathrm{O}_{2}$. From the Rietveld refinement of the XRD patterns, it was suggested that the $\mathrm{LiMgPO}_{4}$ surface-coated layered material was surface-doped, resulting in $\left[\mathrm{Li}_{1.17-y} \mathrm{Mg}_{y}\right]\left[\mathrm{Ni}_{0.17} \mathrm{Co}_{0.17} \mathrm{Mn}_{0.5}\right] \mathrm{O}_{2}$. In the $\mathrm{Li}_{2} \mathrm{MnO}_{3}$ phase, the $\mathrm{Mg}^{2+}$ ions prefer to occupy the $\mathrm{Li}^{+}$ (4h) sites. This suppresses TM migration from the TM layer to the lithium layer, thereby reducing the structural transformation from the layered (space group $R \overline{3} m$ ) to the spinel-like phase. It was also hypothesized that during the coating process, the $\mathrm{Li}_{2} \mathrm{MnO}_{3}$ phase is activated with simultaneous hybrid surface coating, which leads to Li-rich material with better rate capability and initial Coulombic efficiency at $24^{\circ} \mathrm{C}$, compared to the bare material.

Although upon long cycling at room temperature the capacity retention is almost the same for the bare and $1.5 \mathrm{wt} \%$ surface-coated sample, cycling at an elevated temperature of $60{ }^{\circ} \mathrm{C}$ is significantly better for the $1.5 \mathrm{wt} \% \mathrm{LiMgPO}_{4}$-coated samples. The authors show (Figure 6) that the surface-coated sample with $1.5 \mathrm{wt} \% \mathrm{LiMgPO}_{4}$ delivers an initial discharge capacity of $264 \mathrm{mAh} \cdot \mathrm{g}^{-1}$ at a rate of $0.5 \mathrm{C}$ with a capacity retention of $87.1 \%$, whereas the bare sample shows only $33.4 \%$ capacity retention after 75 cycles. The $\mathrm{LiMgPO}_{4}$-coated Li-rich layered material serves as a protective layer that minimizes electrolyte contact with the active material particles, thereby reducing the attack from acidic $\mathrm{HF}$ and eliminating metal dissolution at a high operating temperature. Consequently, in the $\mathrm{LiMgPO}_{4}$-coated Li- and Mn-rich layered material mentioned above, the voltage fade due to cation migration and structural transformation is reduced, thereby enhancing the cycling stability of the cathode material at elevated temperatures.

The atomic layer deposition (ALD) technique has been used to obtain uniform surface coatings with controlled thickness on top of the Li- and Mn-rich cathode materials [63]. Choi et al. coated the acid-treated $0.3 \mathrm{Li}_{2} \mathrm{MnO}_{3} \cdot 0.7 \mathrm{LiMn}_{0.60} \mathrm{Ni}_{0.25} \mathrm{Co}_{0.15} \mathrm{O}_{2}$ composite electrode material with a thin $\mathrm{Al}_{2} \mathrm{O}_{3}$ layer [64]. By the ALD technique, they demonstrated that the alumina-coated electrodes improve 
not only the discharge capacity but also the cycling stability, compared to the uncoated material. After 10 ALD cycles, the 0.1-M- $\mathrm{HNO}_{3}$-treated electrode material coated with $\mathrm{Al}_{2} \mathrm{O}_{3}$ shows better capacity retention. Here, $\mathrm{Al}_{2} \mathrm{O}_{3}$ forms a stable protective layer that can quickly transport $\mathrm{Li}^{+}$ions across the interface of the cathode particles during charging and discharging.

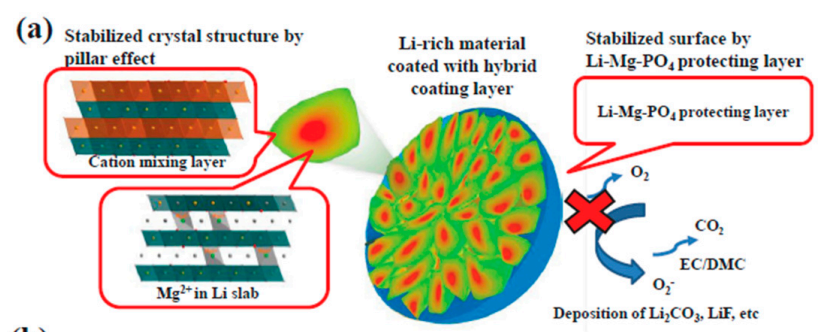

(b)

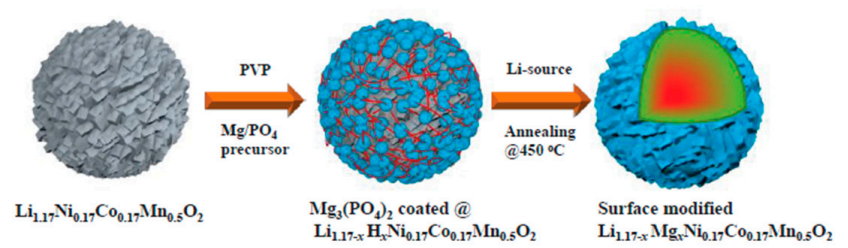

Figure 5. Design of surface-coated high-energy cathode material with a $\mathrm{LiMgPO}_{4}$ protecting layer. (a) Schematic illustration of surface-modified Li-rich cathode particles with the novel hybrid material $\mathrm{LiMgPO}_{4}$; (b) Schematic diagram showing the preparation of surface-coated $\mathrm{Li}_{1.17} \mathrm{Ni}_{0.17} \mathrm{Co}_{0.17} \mathrm{Mn}_{0.5} \mathrm{O}_{2}$ particles from bare material. Reprinted with permission [62]. Copyright 2015, Wiley-VCH Verlag.

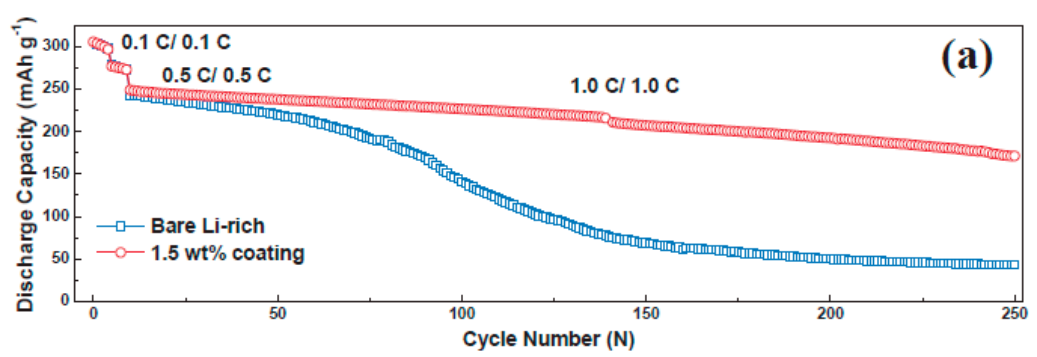

(b)

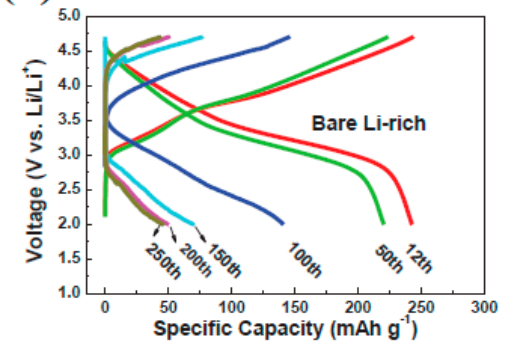

(c)

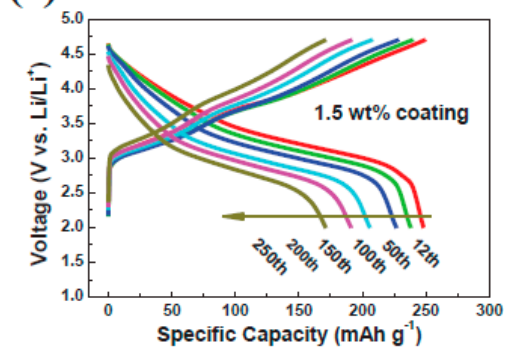

Figure 6. Electrochemical performance of the bare and surface-coated Li- and Mn-rich cathode materials at $60{ }^{\circ} \mathrm{C}$. (a) The discharge capacity versus prolonged cycling of the bare and $1.5 \mathrm{wt} \%$ coated samples at $60{ }^{\circ} \mathrm{C}$ at a $1.0 \mathrm{C} / 1.0 \mathrm{C}$ rate after several formation cycles; $(\mathbf{b}, \mathbf{c})$ The charge/discharge profiles of the bare and $1.5 \mathrm{wt} \%$ surface-modified Li-rich cathode materials. Reprinted with permission [62]. Copyright 2015, Wiley-VCH Verlag.

In a surface-modification technique proposed by $\mathrm{Oh}$ et al., the $\mathrm{Li}$ - and $\mathrm{Mn}$-rich layered-cathode $0.4 \mathrm{Li}_{2} \mathrm{MnO}_{3} \cdot 0.6 \mathrm{LiNi}_{1 / 3} \mathrm{Co}_{1 / 3} \mathrm{Mn}_{1 / 3} \mathrm{O}_{2}$ material was surface-coated with several layers of reduced graphene oxide (rGO) by the spray-dry technique and treated with hydrazine (HGO) solution to obtain a better electronic conducting pathway onto the bare cathode surface [65]. A schematic view of the HGO-coated material is shown in Figure $\mathrm{S} 3$. The $\mathrm{Li}_{2} \mathrm{MnO}_{3}$ phase on the surface is stabilized by 
activating its structure with HGO treatment. This surface treatment of layered cathode materials by HGO greatly increases the initial Coulombic efficiency and mitigates voltage fading upon extended cycling (Figure S4). In this figure, the specific capacities obtained at low rates are almost the same for the pristine and HGO samples, but the rate capabilities are clearly distinguishable at higher rates, mainly due the conducting HGO layer at the surface. Upon long cycling, the surface-treated samples mentioned above demonstrate a stable discharge capacity over 100 cycles, with a capacity retention of $78 \%$, whereas the specific capacity of the uncoated sample falls abruptly after 30 cycles. This improvement in the HGO-coated Li-rich electrodes emerges by suppressing the phase transition of the bulk material from the layered phase to spinel-like phases and rock-salt phases, which is the main reason behind the capacity fading observed in all Li-rich layered cathode materials.

The influence of cation dopants (such as $\mathrm{Mg}^{2+}$ ) in $x \mathrm{Li}_{2} \mathrm{MnO}_{3} \cdot(1-x) \mathrm{Li}\left[\mathrm{Mn}_{y} \mathrm{Ni}_{z} \mathrm{Co}_{w}\right] \mathrm{O}_{2}$ materials was studied by partial replacement of $\mathrm{Mn}$ in a typical material (the general formula $\mathrm{Li}_{1.2} \mathrm{Ni}_{0.16} \mathrm{Mn}_{0.56-x} \mathrm{Mg}_{x} \mathrm{Co}_{0.08} \mathrm{O}_{2}$ ). Two dopant levels were used, $x=0.02$ and $x=0.05$. The material was synthesized by the self-combustion reaction (SCR) from the precursors of $\mathrm{LiNO}_{3}, \mathrm{Ni}\left(\mathrm{NO}_{3}\right)_{2}$, $\mathrm{Mn}\left(\mathrm{NO}_{3}\right)_{2}, \mathrm{Co}\left(\mathrm{NO}_{3}\right)_{2}$ and $\mathrm{Mg}\left(\mathrm{NO}_{3}\right)_{2}$, as reported earlier [66]. These precursors and sucrose act as oxidants and fuel, respectively, in the SCR. The XRD patterns of both samples can be indexed as a hexagonal $\mathrm{O} 3 \alpha-\mathrm{NaFeO}_{2}$ structure (space group $R \overline{3} \mathrm{~m}$ ), with a few broad peaks that appear in the $2 \theta$ range of $20^{\circ}-25^{\circ}$ (Figure S5). These diffraction peaks result from the super-lattice ordering of Li and $\mathrm{Mn}$ in the transition-metal layers associated with the presence of the monoclinic phase $\mathrm{Li}_{2} \mathrm{MnO}_{3}$. No additional XRD peaks were detected upon $\mathrm{Mg}$ doping, indicating the absence of any impurity phase and the proper substitution of $\mathrm{Mg}$ for $\mathrm{Mn}$. The $\mathrm{Mg}$ doping resulted in a slight increase in the lattice parameters and the unit cell volume of the doped material $\left(V=201 \AA^{3}\right)$ compared to the undoped one $\left(V=200.8 \AA^{3}\right)$. This is probably because of the large size of $\mathrm{Mg}^{2+}(0.76 \AA)$ compared to $\mathrm{Mn}^{4+}$ $(0.53 \AA)$. Galvanostatic charge/discharge cycling of the Mg-doped Li- and Mn-rich cathodes was performed vs. Li counter-electrodes in coin-type cells at $25 \mathrm{~mA} \cdot \mathrm{g}^{-1}$ (about C/10 rate). The voltage range was $2.0-4.7 \mathrm{~V}$ in the first cycle and $2.0-4.6 \mathrm{~V}$ in the 100 subsequent cycles. The voltage profiles measured from these electrodes demonstrated a plateau around $4.5 \mathrm{~V}$ corresponding to the activation of $\mathrm{Li}_{2} \mathrm{MnO}_{3}$. However, the first charge voltage plateau region is shortened when the dopant level of $\mathrm{Mg}$ is $x=0.05$. A high specific capacity of about $340 \mathrm{mAh} \cdot \mathrm{g}^{-1}$ was initially obtained for the undoped $\mathrm{Li}_{1.2} \mathrm{Ni}_{0.16} \mathrm{Mn}_{0.56} \mathrm{Co}_{0.08} \mathrm{O}_{2}$ cathodes, while charging capacities of about 348 and $250 \mathrm{mAh} \cdot \mathrm{g}^{-1}$ were measured in the first cycle for the electrodes doped with $\mathrm{Mg}$ at values of $x=0.02$ and $x=0.05$, respectively. This result demonstrates that $\mathrm{Mg}$ doping only slows the initial activation process of the monoclinic $\mathrm{Li}_{2} \mathrm{MnO}_{3}$ component with the higher amount of dopant $(x=0.05)$. This is in agreement with the result reported in the literature for the partial substitution of Mn by Sn [67]. The partial substitution of $\mathrm{Mn}$ by $\mathrm{Mg}$ suppresses the capacity resulting from the activation of $\mathrm{Li}_{2} \mathrm{MnO}_{3}$. This is because the formation of stronger $\mathrm{Mg}-\mathrm{O}$ bonds compared to $\mathrm{Li}-\mathrm{O}$ bonds suppresses the irreversible extraction of $\mathrm{Li}^{+}$and $\mathrm{O}_{2}$ during the charge in the first cycle [68]. The charge/discharge voltage profiles relating to several cycles during the prolonged cycling of $\mathrm{Li}_{1.2} \mathrm{Ni}_{0.16} \mathrm{Mn}_{0.54} \mathrm{Mg}_{0.02} \mathrm{Co}_{0.08} \mathrm{O}_{2}$ and $\mathrm{Li}_{1.2} \mathrm{Ni}_{0.16} \mathrm{Mn}_{0.51} \mathrm{Mg}_{0.05} \mathrm{Co}_{0.08} \mathrm{O}_{2}$ are presented in Figure 7. The wide plateau at potentials higher than $4.5 \mathrm{~V}$ in the first cycle, corresponding to the activation of $\mathrm{Li}_{2} \mathrm{MnO}_{3}$, disappear during the charge in subsequent cycles. In the second cycle, the discharge capacities are found to be about 270 and $170 \mathrm{mAh} \cdot \mathrm{g}^{-1}$ for $\mathrm{Li}_{1.2} \mathrm{Ni}_{0.16} \mathrm{Mn}_{0.54} \mathrm{Mg}_{0.02} \mathrm{Co}_{0.08} \mathrm{O}_{2}$ and $\mathrm{Li}_{1.2} \mathrm{Ni}_{0.16} \mathrm{Mn}_{0.51} \mathrm{Mg}_{0.05} \mathrm{Co}_{0.08} \mathrm{O}_{2}$, with a Coulombic efficiency approaching $99 \%$. As established earlier, there is a decrease in the specific capacity and discharge voltage decay of the undoped electrode materials upon cycling. In our experiments, the Mg-doped ( $x=0.02)$ samples demonstrate this effect [69]. However, when the $\mathrm{Mg}$-doping level is 0.05 for $\mathrm{Li}_{1.2} \mathrm{Ni}_{0.16} \mathrm{Mn}_{0.51} \mathrm{Mg}_{0.05} \mathrm{Co}_{0.08} \mathrm{O}_{2}$, the specific capacity increases during the initial 20-30 cycles and stabilizes at about $230 \mathrm{mAh} \cdot \mathrm{g}^{-1}$.

The specific capacity obtained from galvanostatic cycling at a rate of $\mathrm{C} / 10$ as a function of the cycle number is shown in Figure 8. In the case of the $\mathrm{Li}_{1.2} \mathrm{Ni}_{0.16} \mathrm{Mn}_{0.56} \mathrm{Co}_{0.08} \mathrm{O}_{2}$ electrodes, a discharge capacity of $250 \mathrm{mAh} \cdot \mathrm{g}^{-1}$ is obtained in the second cycle, which decreases to $175 \mathrm{mAh} \cdot \mathrm{g}^{-1}$, 
thus retaining about $70 \%$ capacity after 100 cycles (Figure 8 ). For the $\mathrm{Li}_{1.2} \mathrm{Ni}_{0.16} \mathrm{Mn}_{0.54} \mathrm{Mg}_{0.02} \mathrm{Co}_{0.08} \mathrm{O}_{2}$ cathodes, the specific capacity drops from $270 \mathrm{mAh} \cdot \mathrm{g}^{-1}$ (second discharge) to $220 \mathrm{mAh} \cdot \mathrm{g}^{-1}$, thus retaining about $81.5 \%$ capacity after 100 cycles (Figure $8 \mathrm{ii}$ ). The specific capacity of the $\mathrm{Li}_{1.2} \mathrm{Ni}_{0.16} \mathrm{Mn}_{0.51} \mathrm{Mg}_{0.05} \mathrm{Co}_{0.08} \mathrm{O}_{2}$ electrodes increases from $170 \mathrm{mAh} \cdot \mathrm{g}^{-1}$ (second discharge) to $230 \mathrm{mAh} \cdot \mathrm{g}^{-1}$ after about 20 cycles, finally decreasing to $210 \mathrm{mAh} \cdot \mathrm{g}^{-1}$, with a capacity retention of about $91.3 \%$ (Figure 8iii). Such an increase in capacity during the first few cycles indicates, again, the gradual activation of $\mathrm{Li}_{1.2} \mathrm{Ni}_{0.16} \mathrm{Mn}_{0.51} \mathrm{Mg}_{0.05} \mathrm{Co}_{0.08} \mathrm{O}_{2}$ upon cycling, which is in line with previous reports [68]. Hence, the minor substitution of $\mathrm{Mn}$ by $\mathrm{Mg}$ results in an improvement in the cycling stability during prolonged cycling of these Li- and Mn-rich cathodes.
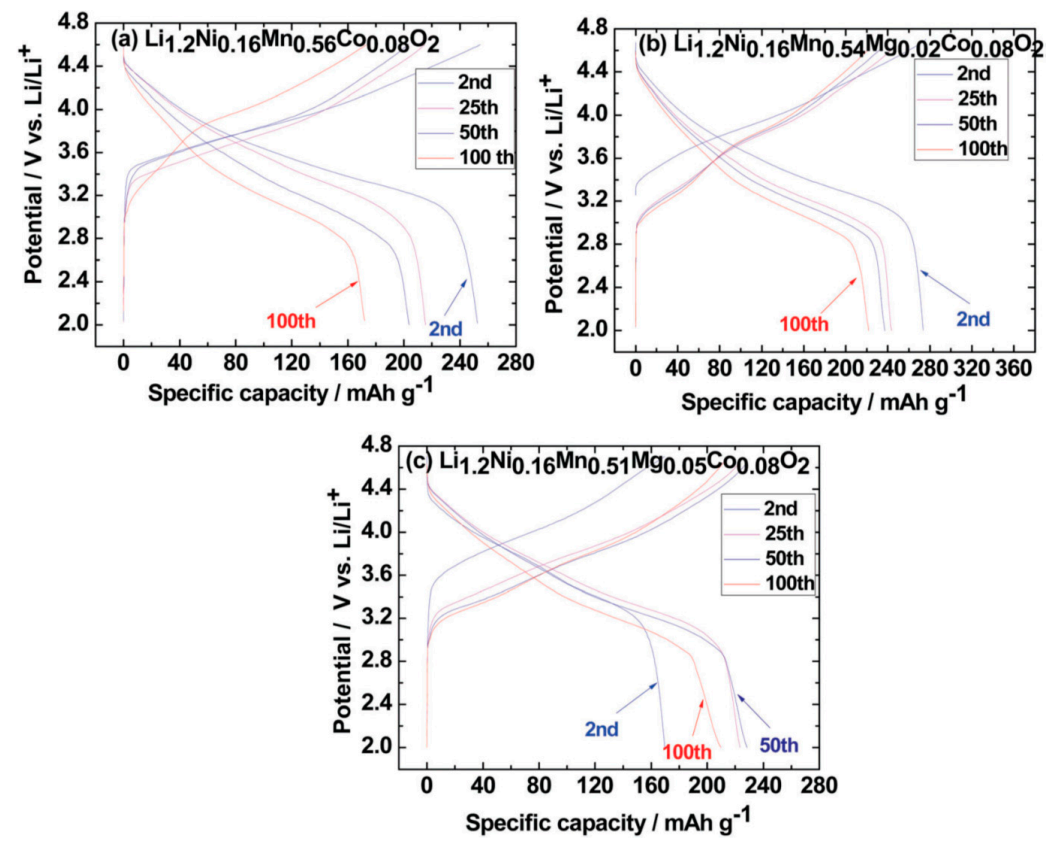

Figure 7. Voltage profiles measured from selected cycles (as indicated) of $\mathrm{Li}_{1.2} \mathrm{Ni}_{0.16} \mathrm{Mn}_{0.56-x} \mathrm{Mg}_{x} \mathrm{Co}_{0.08} \mathrm{O}_{2}$ $\left(x=0.00\right.$ (a) 0.02 (b), 0.05 (c)) cathodes cycled galvanostatically at $20 \mathrm{~mA} \cdot \mathrm{g}^{-1}$ (C/10 rate). The potential range is 2.0-4.6 V. Coin-type cells, $1 \mathrm{M} \mathrm{LiPF}_{6}$ in EC:DMC (1:1) solutions. Reprinted from [70].

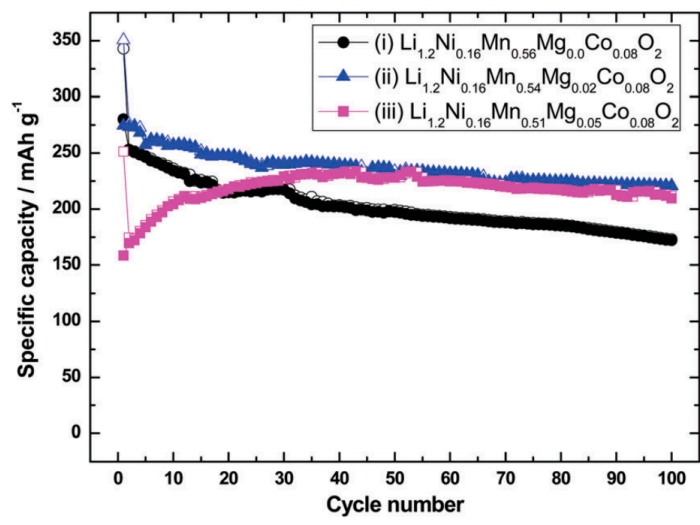

Figure 8. Specific capacity as a function of cycle number, measured from undoped (i) $\mathrm{Li}_{1.2} \mathrm{Ni}_{0.16} \mathrm{Mn}_{0.56} \mathrm{Co}_{0.08} \mathrm{O}_{2}$, Mg-doped (ii) $\mathrm{Li}_{1.2} \mathrm{Ni}_{0.16} \mathrm{Mn}_{0.54} \mathrm{Mg}_{0.02} \mathrm{Co}_{0.08} \mathrm{O}_{2}$ and (iii) $\mathrm{Li}_{1.2} \mathrm{Ni}_{0.16} \mathrm{Mn}_{0.51} \mathrm{Mg}_{0.05} \mathrm{Co}_{0.08} \mathrm{O}_{2}$ electrodes at $30^{\circ} \mathrm{C}$. The first cycle was carried out at $4.7 \mathrm{~V}$ and the rest were carried out over the potential range of $2.0-4.6 \mathrm{~V}$, at a rate of $\mathrm{C} / 10$. Empty and filled symbols stand for charge and discharge capacities, respectively. Coin-type cells, EC-DMC/1M LiPF 6 solutions. Reprinted from [70]. 


\subsection{Low-Temperature Activation of $x \mathrm{Li}_{2} \mathrm{MnO}_{3} \cdot(1-x) \mathrm{Li}\left[\mathrm{Mn}_{y} \mathrm{Ni}_{z} \mathrm{Co}_{w}\right] \mathrm{O}_{2}$ Materials}

Recently, our group has discovered a unique phenomenon: the activation of Li- and $\mathrm{Mn}$-rich materials at lower than ambient temperatures (e.g., 0 or $15{ }^{\circ} \mathrm{C}$ ) results in a $\sim 10 \%$ enhancement in the subsequent discharge capacity of these materials [41,71]. This effect has been shown in multiple formulations of $x \mathrm{Li}_{2} \mathrm{MnO}_{3} \cdot(1-x) \mathrm{Li}\left[\mathrm{Mn}_{y} \mathrm{Ni}_{z} \mathrm{Co}_{w}\right] \mathrm{O}_{2}$. The results for two different materials are depicted in Figure 9 [41,71]. The mechanism behind the enhanced discharge capacity from low-temperature activation is still under investigation. Since the first cycle of the $\mathrm{Li}$ - and $\mathrm{Mn}$-rich materials must be extended to higher potentials, at which electrolyte oxidation is enhanced, the surface films may play a role, showing lower resistance for cells activated at lower temperatures [41,71].

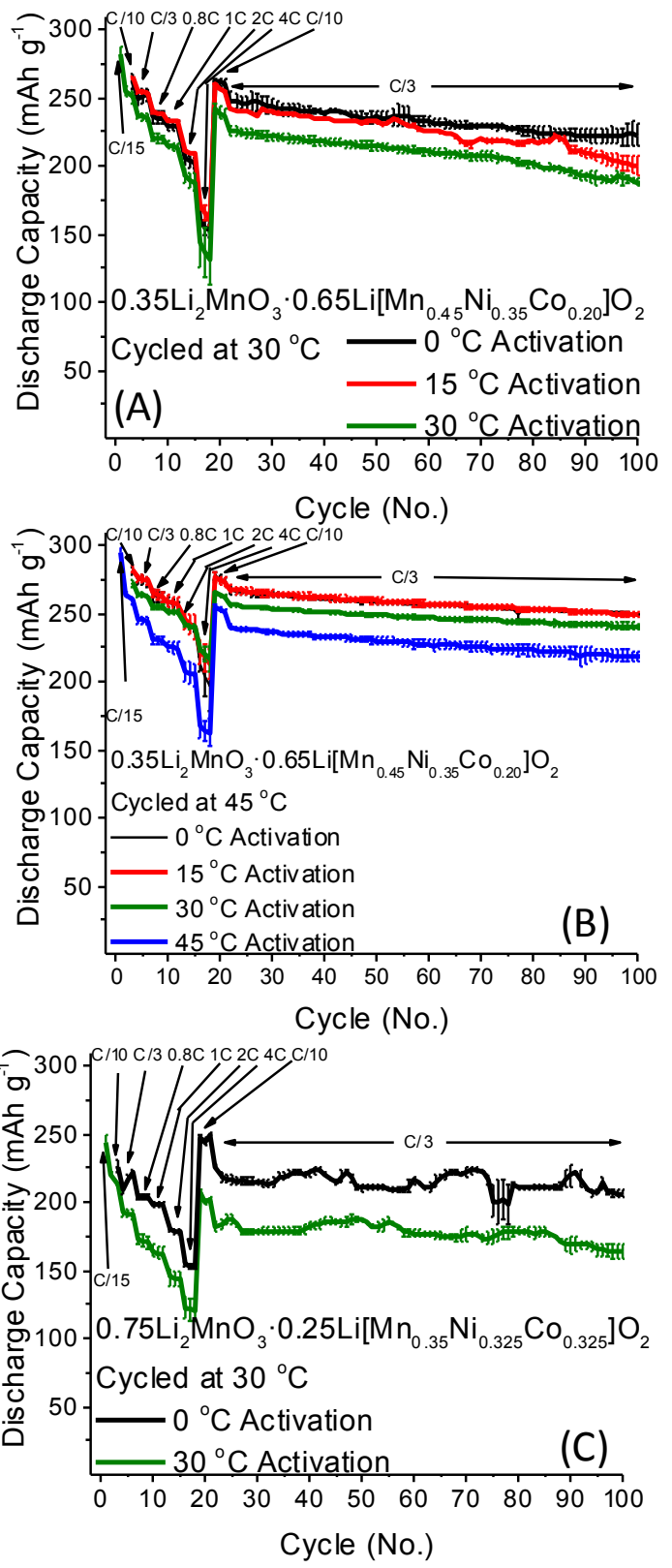

Figure 9. Low-temperature activation of electrodes comprising different compositions of Li- and Mn-rich materials. $0.35 \mathrm{Li}_{2} \mathrm{MnO}_{3} \cdot 0.65 \mathrm{Li}\left[\mathrm{Mn}_{0.45} \mathrm{Ni}_{0.35} \mathrm{Co}_{0.20}\right] \mathrm{O}_{2}$ cycled at (A) 30 and (B) $45^{\circ} \mathrm{C}$ after the first two cycles, which were performed at $0-45^{\circ} \mathrm{C}$ as indicated. Reprinted from Erickson et al. with permission [71]; (C) $0.75 \mathrm{Li}_{2} \mathrm{MnO}_{3} \cdot 0.25 \mathrm{Li}\left[\mathrm{Mn}_{0.45} \mathrm{Ni}_{0.35} \mathrm{Co}_{0.20}\right] \mathrm{O}_{2}$ cycled at $30{ }^{\circ} \mathrm{C}$ after the first two cycles, which were performed at 0 and $30^{\circ} \mathrm{C}$ as indicated. Modified from [41]. 


\subsection{Porous Li- and Mn-Rich High-Energy-Density Cathode Materials}

As discussed above, Li- and Mn-rich cathodes present thermodynamic and kinetic challenges, such as low Coulombic efficiency, poor rate capability and fast capacity fading. To overcome these issues, metal-ion doping of the lattice and surface modifications by coating are being adopted. Another approach is to focus on the fabrication of nanostructured cathode materials with well-defined morphologies, such as porous structures and hollow spheres. The selection of nano-sized materials potentially improves the mass transport of the cathode by increasing its surface area, shorting the diffusion lengths and providing higher intercalation/deintercalation rates. Apart from the advantages of the high specific surface area of the nanoparticles, the nano-sized materials show certain disadvantages: the lowering of thermodynamic stability, higher contact resistance, low packing density and high side reactions at the electrode/electrolyte solution interface. Therefore, these materials cannot be used in practical applications. Compared to nanomaterials, micrometer-sized particles have relatively high thermodynamic stability, low contact resistance and low specific surface area, and they exhibit less side reactions. In contrast, the advantage in porous structured materials is their good electrode/electrolyte solution interface through the pores and promising structural stability via low contact resistance through the walls of the pores. Therefore, electrodes prepared from porous materials are expected to possess high rate capability, since the electrolyte can seep into the particles and enhance the contact area of the electroactive surface with the electrolyte. This shortens the diffusion length of $\mathrm{Li}^{+}$-ion transport and enhances the kinetics [72,73]. As a result, these materials can withstand high currents during charge/discharge cycling. Furthermore, the electrode material can tolerate the volume expansion and contraction that may occur during Li intercalation/deintercalation processes.

Porous materials can be classified as microporous $(<2 \mathrm{~nm})$, mesoporous $(2-50 \mathrm{~nm})$, and macroporous $(>50 \mathrm{~nm})$, based on the pore size. They are prepared by various synthetic routes, such as template and non-template methods. Non-template methods are hydrothermal, sonication and microwave routes. Template methods use a substrate on which the material nucleates, grows and then the product can be separated from the substrate. There are several kinds of templates: soft templates (polymers), hard templates $\left(\mathrm{SiO}_{2}\right.$, polymer beads) and self-templates (one of the precursors, which acts as a template). In Table S1, which presents an overview of the literature data on porous cathode materials for Li-ion batteries (LIBs), we demonstrate the relation between the synthetic method of porous materials and their electrochemical performance. In addition, several approaches are discussed below with detailed benefits of using porous materials.

Li- and Mn-rich $\mathrm{Li}_{1.2} \mathrm{Mn}_{0.54} \mathrm{Ni}_{0.13} \mathrm{Co}_{0.13} \mathrm{O}_{2}$ material with hierarchical porous micro-sized rods was prepared by the facile hydrothermal method, with discharge capacities of about 281, 255, 232, 226, 202 and $173 \mathrm{mAh} \cdot \mathrm{g}^{-1}$, at rates of $0.1 \mathrm{C}, 0.2 \mathrm{C}, 0.5 \mathrm{C}, 1 \mathrm{C}, 2 \mathrm{C}$ and $5 \mathrm{C}$, respectively, measured as shown in Figure S6A [74]. Ma et al. [75] reported hierarchical $\mathrm{Li}_{1.165} \mathrm{Mn}_{0.501} \mathrm{Ni}_{0.167} \mathrm{Co}_{0.167} \mathrm{O}_{2}$, which was prepared by the ultrasonic-assisted co-precipitation method with two steps of heat treatment by adopting graphene and carbon nanotubes as the functional framework. These materials exhibit the specific capacity of $277 \mathrm{mAh} \cdot \mathrm{g}^{-1}$ at a rate of $0.1 \mathrm{C}$ and $61 \mathrm{mAh} \cdot \mathrm{g}^{-1}$ at a rate of $10 \mathrm{C}$ (Figure S6B). Munichandraiah et al. prepared porous $\mathrm{Li}$ - and $\mathrm{Mn}$-rich cathodes $\left(\mathrm{Li}_{1.2} \mathrm{Mn}_{0.53} \mathrm{Ni}_{0.13} \mathrm{Co}_{0.13} \mathrm{O}_{2}\right.$, $\mathrm{Li}_{1.2} \mathrm{Mn}_{0.54} \mathrm{Ni}_{0.22} \mathrm{Fe}_{0.04} \mathrm{O}_{2}, \mathrm{Li}_{1.2} \mathrm{Mn}_{0.53} \mathrm{Ni}_{0.13} \mathrm{Fe}_{0.132}, \mathrm{Li}_{1.2} \mathrm{Mn}_{0.6} \mathrm{Ni}_{0.2} \mathrm{O}_{2}$ ) by the reverse micro-emulsion method using a tri-block co-polymer as a soft template [76-79]. Soft-template synthesis by the inverse micro-emulsion route is useful for the preparation of small particles. When a small volume of an aqueous phase consisting of the reactants is dispersed in a large volume of a non-aqueous phase, the reactants are confined to micrometer-sized aqueous reaction zones and the size of the product particles is limited to the size of the aqueous droplets, which are stabilized by surfactant molecules. Sub-micrometer/nanometer-sized particles were synthesized by this route [80]. The typical reverse micro-emulsion route contains hydrocarbon (aliphatic or aromatic) as an oil phase, co-surfactant (4 to 8 carbon-chain aliphatic alcohol) and a small amount of aqueous phase. As shown in the schematic diagram in Figure 10a, the presence of tri-block polymeric templates such as P123, F068 and F127 is expected to facilitate porosity on the product particles. These templates follow the general formula 
$-\left[(\mathrm{EO})_{n}-(\mathrm{PO})_{m}-(\mathrm{EO})_{n}\right]-,(n=20, m=70$ for P123, $n=78, m=30$ for F068, $n=106, m=70$ for F127), where $\mathrm{EO}$ and $\mathrm{PO}$ are ethylene oxide and propylene oxide, respectively.
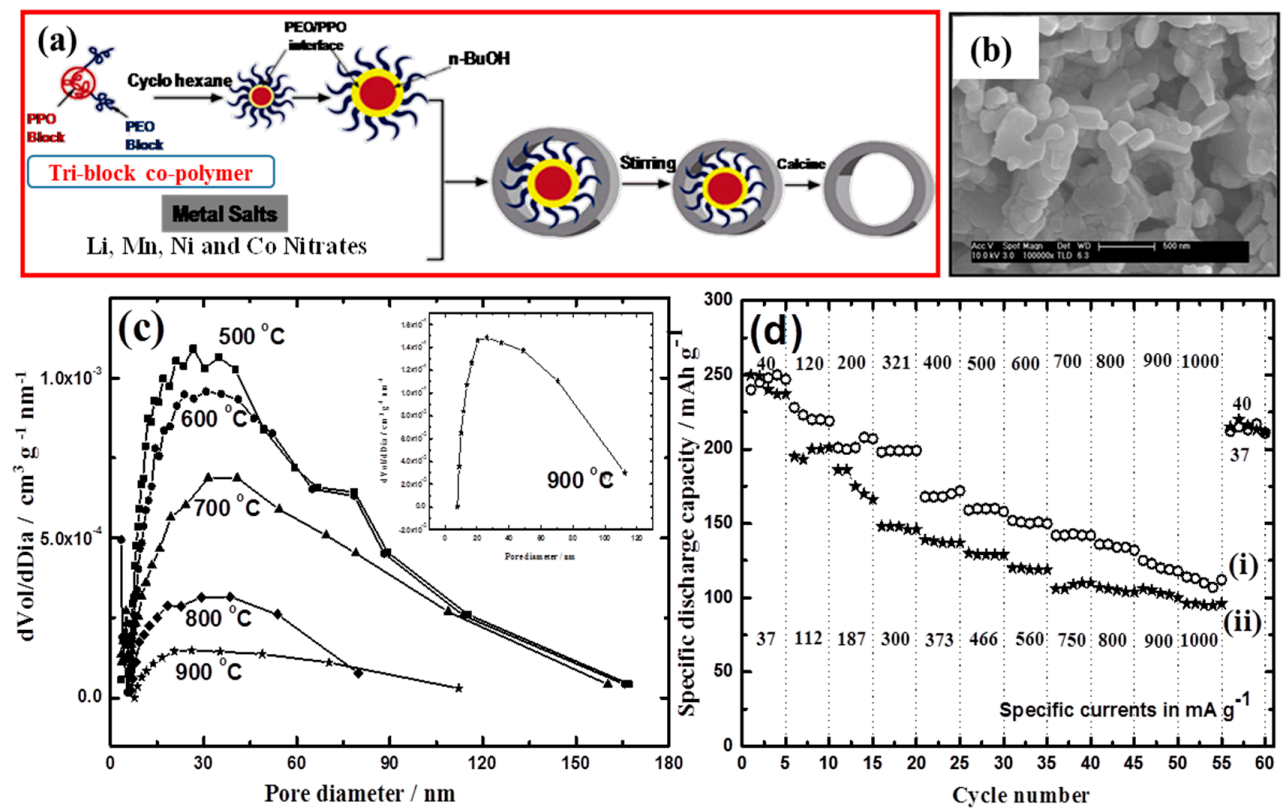

Figure 10. (a) Schematic diagram of the inverse micro-emulsion route using a tri-block co-polymer as a soft template for producing electrode materials; (b) SEM image of $0.5 \mathrm{Li}_{2} \mathrm{MnO}_{3} \cdot 0.5 \mathrm{LiMn}_{1 / 3} \mathrm{Ni}_{1 / 3} \mathrm{Co}_{1 / 3} \mathrm{O}_{2}$ sample heated to $900{ }^{\circ} \mathrm{C}$; (c) pore-size-distribution $(\mathrm{BJH})$ curves of $0.5 \mathrm{Li}_{2} \mathrm{MnO}_{3} \cdot 0.5 \mathrm{LiMn}_{1 / 3} \mathrm{Ni}_{1 / 3} \mathrm{Co}_{1 / 3} \mathrm{O}_{2}$ samples heated to $500,600,700,800$ and $900{ }^{\circ} \mathrm{C}$ (in the inset), as indicated; and (d) rate capability of $0.5 \mathrm{Li}_{2} \mathrm{MnO}_{3} \cdot 0.5 \mathrm{LiMn}_{1 / 3} \mathrm{Ni}_{1 / 3} \mathrm{Co}_{1 / 3} \mathrm{O}_{2}$ electrode samples heated to $800{ }^{\circ} \mathrm{C}$ (i) and $900{ }^{\circ} \mathrm{C}$ (ii). Reprinted from [77].

The combination of a hydrophobic and hydrophilic PO block leads to the creation of porosity [81]. Sub-micrometer-sized porous cathode materials can be synthesized by combining the salient features of inverse micro-emulsion and the polymeric template. The precursor of the porous $\mathrm{Li}_{1.2} \mathrm{Mn}_{0.53} \mathrm{Ni}_{0.13} \mathrm{Co}_{0.13} \mathrm{O}_{2}$ is heated to several temperatures between 500 and $900{ }^{\circ} \mathrm{C}$. The product samples possess mesoporosity with broadly distributed pores, with about 30-nm diameters (Figure 10C). Note that there is a decrease in the pore volume as well as in the surface area with the increase in the temperature of preparation. The discharge capacity of the $\mathrm{Li}_{1.2} \mathrm{Mn}_{0.53} \mathrm{Ni}_{0.13} \mathrm{Co}_{0.13} \mathrm{O}_{2}$ samples prepared at 800 and $900^{\circ} \mathrm{C}$ is $\sim 250 \mathrm{mAh} \cdot \mathrm{g}^{-1}$ at a specific current of $40 \mathrm{~mA} \cdot \mathrm{g}^{-1}$, showing good cycling stability and rate capability (Figure 10D).

A hierarchically porous layered lithium-rich oxide, $0.5 \mathrm{Li}_{2} \mathrm{MnO}_{3} \cdot 0.5 \mathrm{LiMn}_{1 / 3} \mathrm{Ni}_{1 / 3} \mathrm{Co}_{1 / 3} \mathrm{O}_{2}$, was synthesized by the co-precipitation of metal oxalates, with the assistance of a moderate polyethylene glycol (PEG2000) [82]. It was found that the as-synthesized oxide exhibits excellent rate capability and cyclic stability as an electrode in Li-cells, delivering an initial discharge capacity of $262 \mathrm{mAh} \cdot \mathrm{g}^{-1}$ at $0.1 \mathrm{C}$ and $135 \mathrm{mAh} \cdot \mathrm{g}^{-1}$ at $4 \mathrm{C}$, and possessing a capacity retention of $83 \%$ after 200 cycles at $4 \mathrm{C}$. The discharge profiles and corresponding $\mathrm{d} Q / \mathrm{d} V$ plots are shown in Figure 11. Both samples display a similar trend in voltage fading, as can be seen by the decreasing potential profiles with increasing cycle numbers (Figure 11A,C), but without PEG-0.5 $\mathrm{Li}_{2} \mathrm{MnO}_{3} \cdot 0.5 \mathrm{LiMn}_{1 / 3} \mathrm{Ni}_{1 / 3} \mathrm{Co}_{1 / 3} \mathrm{O}_{2}$ electrodes exhibit a more serious decline in discharge capacity than electrodes comprising PEG2000-0.5 $\mathrm{Li}_{2} \mathrm{MnO}_{3} \cdot 0.5 \mathrm{LiMn}_{1 / 3} \mathrm{Ni}_{1 / 3} \mathrm{Co}_{1 / 3} \mathrm{O}_{2}$ composite material. This result shows that PEG2000-0.5 $\mathrm{Li}_{2} \mathrm{MnO}_{3} \cdot 0.5 \mathrm{LiMn}_{1 / 3} \mathrm{Ni}_{1 / 3} \mathrm{Co}_{1 / 3} \mathrm{O}_{2}$ has better structural stability than $0.5 \mathrm{Li}_{2} \mathrm{MnO}_{3} \cdot 0.5 \mathrm{LiMn}_{1 / 3} \mathrm{Ni}_{1 / 3} \mathrm{Co}_{1 / 3} \mathrm{O}_{2}$. This difference between the two materials can be more easily observed from the $\mathrm{d} Q / \mathrm{d} V$ plots in Figure 11B,D. Three main reduction processes (which accompany Li-intercalation) can be identified: Re1 at about $4.5 \mathrm{~V}$ is related to Li occupation in the 
tetrahedral sites; Re2 at $3.7 \mathrm{~V}$ can be ascribed to Li occupation in the octahedral sites corresponding to $\mathrm{Ni}^{4+} / \mathrm{Ni}^{2+}$ and $\mathrm{Co}^{4+} / \mathrm{Co}^{3+}$; and $\mathrm{Re} 3$ at $<3.5 \mathrm{~V}$ can be explained by Li occupation in the octahedral sites associated with $\mathrm{Mn}^{4+} / \mathrm{Mn}^{3+}$ redox [83,84]. Further delithiation beyond $4.5 \mathrm{~V}$ during the first cycle leads to oxygen vacancies and the subsequent migration of transition metal ions into lithium sites and lithium ions into tetrahedral sites, resulting in a distorted oxygen lattice [85-88]. Figure 11B,D shows that all the reduction peaks shift with cycling, but the shifting is more serious for $0.5 \mathrm{Li}_{2} \mathrm{MnO}_{3} \cdot 0.5 \mathrm{LiMn}_{1 / 3} \mathrm{Ni}_{1 / 3} \mathrm{Co}_{1 / 3} \mathrm{O}_{2}$ than for PEG2000-0.5 $\mathrm{Li}_{2} \mathrm{MnO}_{3} \cdot 0.5 \mathrm{LiMn}_{1 / 3} \mathrm{Ni}_{1 / 3} \mathrm{Co}_{1 / 3} \mathrm{O}_{2}$. This observation reveals that PEG2000-0.5 $\mathrm{Li}_{2} \mathrm{MnO}_{3} \cdot 0.5 \mathrm{LiMn}_{1 / 3} \mathrm{Ni}_{1 / 3} \mathrm{Co}_{1 / 3} \mathrm{O}_{2}$ is more structurally stable than $0.5 \mathrm{Li}_{2} \mathrm{MnO}_{3} \cdot 0.5 \mathrm{LiMn}_{1 / 3} \mathrm{Ni}_{1 / 3} \mathrm{Co}_{1 / 3} \mathrm{O}_{2}$ under deep cycling.
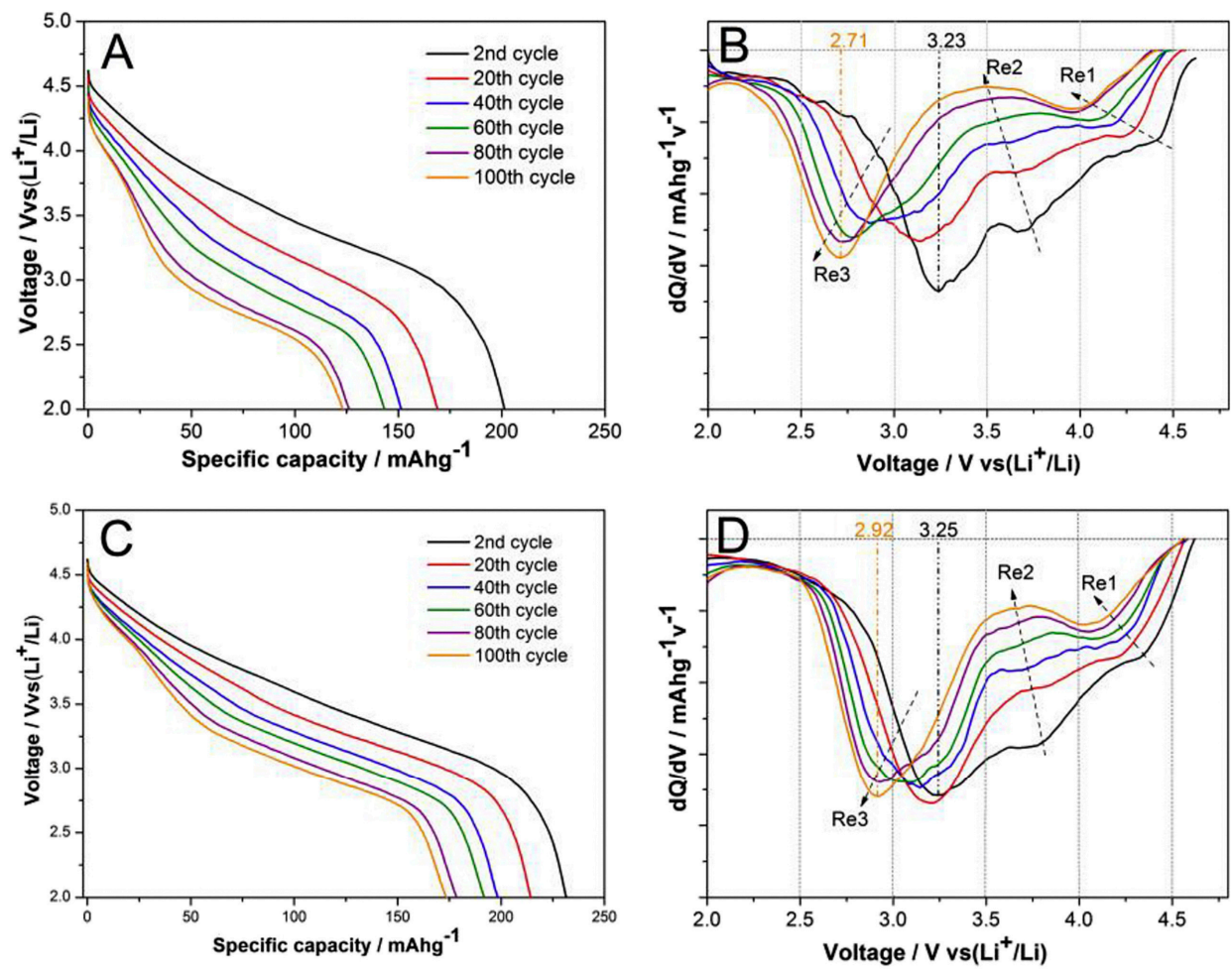

Figure 11. Typical discharge curves and corresponding differential capacity curves of $0.5 \mathrm{Li}_{2} \mathrm{MnO}_{3} \cdot 0.5 \mathrm{LiMn}_{1 / 3} \mathrm{Ni}_{1 / 3} \mathrm{Co}_{1 / 3} \mathrm{O}_{2}(\mathbf{A}, \mathbf{B})$ and PEG2000-0.5 $\mathrm{Li}_{2} \mathrm{MnO}_{3} \cdot 0.5 \mathrm{LiMn}_{1 / 3} \mathrm{Ni}_{1 / 3} \mathrm{Co}_{1 / 3} \mathrm{O}_{2}$ (C,D) electrodes cycled between 2.0 and $4.8 \mathrm{~V}$ at $0.2 \mathrm{C}\left(50 \mathrm{~mA} \cdot \mathrm{g}^{-1}\right)$. Reprinted with permission [82]. Copyright 2015, Elsevier.

The porous $\mathrm{Li}_{1.2} \mathrm{Ni}_{0.13} \mathrm{Co}_{0.13} \mathrm{Mn}_{0.54} \mathrm{O}_{2}$ nanoplate was prepared by a colloidal crystal template assembled by poly(methyl methacrylate) (PMMA) beads [89]. In Figure S7, the cycling performance of the porous $\mathrm{Li}_{1.2} \mathrm{Ni}_{0.13} \mathrm{Co}_{0.13} \mathrm{Mn}_{0.54} \mathrm{O}_{2}$ and bulk $\mathrm{Li}_{1.2} \mathrm{Ni}_{0.13} \mathrm{Co}_{0.13} \mathrm{Mn}_{0.54} \mathrm{O}_{2}$ materials are compared at different discharge rates over the voltage range of 2.0-4.8 V. During the rate capability studies, all the charging steps were carried out at $0.1 \mathrm{C}$ and the discharge was performed over the range of $0.1-1 \mathrm{C}$ rates. Clearly, the porous $\mathrm{Li}_{1.2} \mathrm{Ni}_{0.13} \mathrm{Co}_{0.13} \mathrm{Mn}_{0.54} \mathrm{O}_{2}$ shows higher discharge capacity than the bulk $\mathrm{Li}_{1.2} \mathrm{Ni}_{0.13} \mathrm{Co}_{0.13} \mathrm{Mn}_{0.54} \mathrm{O}_{2}$ at all C-rates. These results indicate that porous $\mathrm{Li}_{1.2} \mathrm{Ni}_{0.13} \mathrm{Co}_{0.13} \mathrm{Mn}_{0.54} \mathrm{O}_{2}$ cathode material shows high specific capacity and improved cycling stability compared to the bulk $\mathrm{Li}_{1.2} \mathrm{Ni}_{0.13} \mathrm{Co}_{0.13} \mathrm{Mn}_{0.54} \mathrm{O}_{2}$ prepared by the traditional method. Nanoparticles of the layered Li- and Mn-rich cathode $\mathrm{Li}\left[\mathrm{Li}_{0.2} \mathrm{Ni}_{0.2} \mathrm{Mn}_{0.6} \mathrm{O}_{2}\right.$ were synthesized via two-step hydrothermal reactions combined with a calcination process, where carbon spheres were used as templates. This cathode material delivers optimal cycling ability, minimal voltage decay and maximal discharge capacities of 239, 219, 205 and $183 \mathrm{mAh} \cdot \mathrm{g}^{-1}$ at rates of 1, 2, 5 and $10 \mathrm{C}$, respectively [90]. 
In the past, the hollow nanostructured electrode materials were generally prepared by template methods, and the removal of the templates was difficult [72]. In contrast, self-template or sacrificial-template methods are convenient for the preparation of hollow materials. The self-template not only acts as a reactant precursor, but also allows the formation of hollow particles [91,92]. Hollow $0.3 \mathrm{Li}_{2} \mathrm{MnO}_{3} \cdot 0.7 \mathrm{LiNi}_{0.5} \mathrm{Mn}_{0.5} \mathrm{O}_{2}$ microspheres were synthesized on a large scale through a simple in situ template-sacrificial route. Starting from porous $\mathrm{MnO}_{2}$ microspheres, hollow microspheres assembled with $0.3 \mathrm{Li}_{2} \mathrm{MnO}_{3} \cdot 0.7 \mathrm{LiNi}_{0.5} \mathrm{Mn}_{0.5} \mathrm{O}_{2}$ nanocrystals were produced (Figure 12) [93]. This material exhibits a highly reversible capacity of about $295 \mathrm{mAh} \cdot \mathrm{g}^{-1}$ over 100 cycles and excellent rate capability $\left(125 \mathrm{mAh} \cdot \mathrm{g}^{-1}\right.$ at $\left.1000 \mathrm{~mA} \cdot \mathrm{g}^{-1}\right)$ as a cathode in Li-cells. An important advantage is that dual and multi-porous $\mathrm{Li}$ - and Mn-rich materials with an advantageous distribution of pores between $2-5 \mathrm{~nm}$ and $30-50 \mathrm{~nm}$. While small pores act as transport channels for ions to the bulk of the electrode, larger pores allow for easy mass transport of solvated ions [94,95].

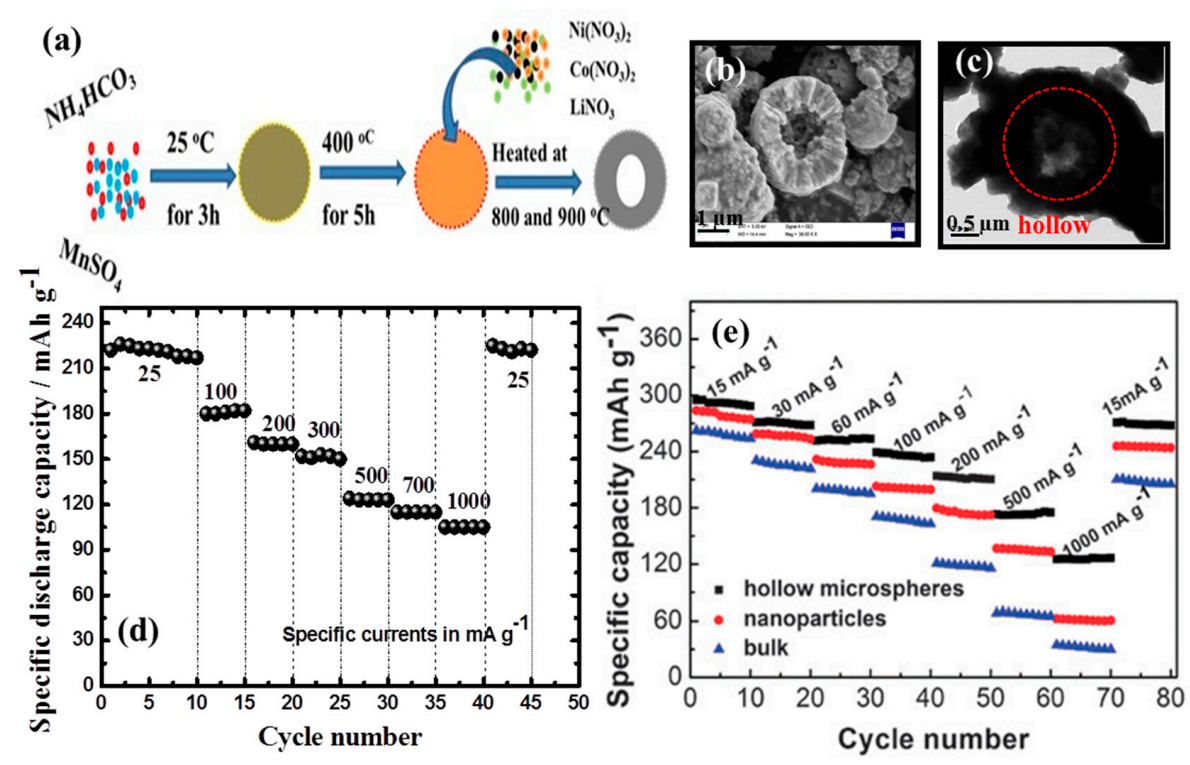

Figure 12. (a) Schematic illustration of the formation of hollow Li-rich materials; (b,c) SEM and TEM images of hollow Li-rich $\mathrm{Li}_{1.2} \mathrm{Mn}_{0.54} \mathrm{Ni}_{0.13} \mathrm{Co}_{0.13} \mathrm{O}_{2}$ material; (d) Rate capability of $\mathrm{Li}_{1.2} \mathrm{Mn}_{0.54} \mathrm{Ni}_{0.13} \mathrm{Co}_{0.13} \mathrm{O}_{2}$ electrode sample, current densities $\left(\mathrm{mA} \cdot \mathrm{g}^{-1}\right)$ are indicated; $(\mathbf{e})$ A comparison of the rate capabilities of electrodes comprising hollow microspheres, nanoparticles and bulk $0.3 \mathrm{Li}_{2} \mathrm{MnO}_{3} \cdot 0.7 \mathrm{LiNi}_{0.5} \mathrm{Mn}_{0.5} \mathrm{O}_{2}$ materials. Reprinted with permission $[89,93]$. Copyright 2017, Springer, and 2013, Royal Society of Chemistry.

\section{Nickel-Rich Li[Ni $\left.\mathrm{Co}_{\mathrm{y}} \mathrm{Mn}_{\mathrm{z}}\right] \mathrm{O}_{2}$ Layered Structure Materials (NCM, $x>0.5, x+y+z=1$ )}

\subsection{Zirconium and Aluminum Doping of $\mathrm{Li}\left[\mathrm{Ni}_{x} \mathrm{Co}_{y} \mathrm{Mn}_{z}\right] \mathrm{O}_{2}$ Materials}

Doping of $\mathrm{Li}\left[\mathrm{Ni}_{x} \mathrm{Co}_{y} \mathrm{Mn}_{z}\right] \mathrm{O}_{2}$ Ni-rich cathode materials with various cations (such as $\mathrm{Fe}^{3+}, \mathrm{Cu}^{2+}$, $\mathrm{Cr}^{3+}, \mathrm{Mg}^{2+}, \mathrm{Al}^{3+}$ and $\mathrm{Zr}^{4+}$ ) has been reported to enhance their electrochemical behavior [68,96-101]. Dopants play various roles in the material. On the one hand, they can act as pillars in the lithium layers and lead to the suppression of $c$-lattice contraction at the end of the charge, resulting in improved rate capability of the electrode [96]. Furthermore, with dopants occupying lithium sites, the $\mathrm{Li}^{+} / \mathrm{Ni}^{2+}$ mixing can be reduced and, hence, the formation of inactive rock salt on the surface is suppressed, resulting in lower charge-transfer-resistance growth with cycling [96,97,102]. Since most of the synthetic strategies of NCM make use of the lithium excess to achieve the correct stoichiometry and minimize the cation mixing during annealing, the material has some excess lithium on the surface. Hence, dopants and surface coatings may react with the surface lithium to form lithium conductive layers [103]. 
We have recently reported the beneficial impact of zirconium doping in NCM622 [96]. The materials under examination were $\mathrm{LiNi}_{0.6} \mathrm{Co}_{0.2} \mathrm{Mn}_{0.2} \mathrm{O}_{2}$ and $\mathrm{LiNi}_{0.54} \mathrm{Zr}_{0.04} \mathrm{Co}_{0.2} \mathrm{Mn}_{0.2} \mathrm{O}_{2}$, synthesized by a self-combustion reaction and annealed at $800{ }^{\circ} \mathrm{C}$ under oxygen flow. Based on computational considerations, the $\mathrm{Ni}^{2+} / \mathrm{Ni}^{3+}$ ratio was calculated for zirconium doping in place of cobalt, nickel or manganese (Figure 13). Since $\mathrm{Zr}^{4+}$ is electrochemically inactive, doping results in a lower NCM capacity. To compensate for this, $\mathrm{Ni}$ was chosen as a substitute, since we have already established the increase in the $\mathrm{Ni}^{2+} / \mathrm{Ni}^{3+}$ ratio. With more $\mathrm{Ni}^{2+}$ ions available in the material, the capacity offset induced by the $\mathrm{Zr}$ doping can be compensated.

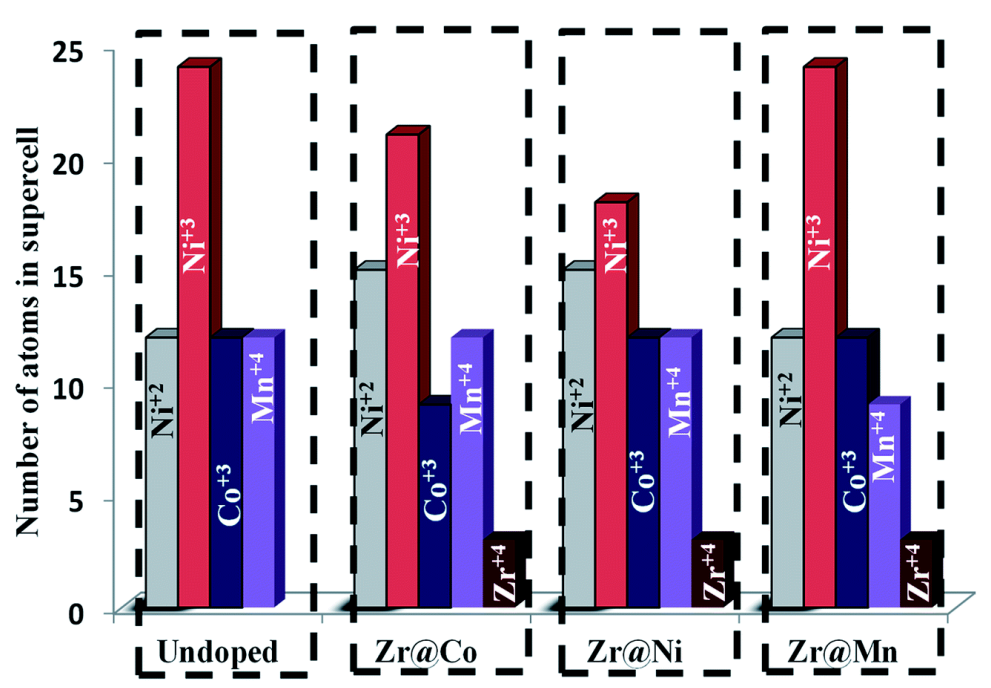

Figure 13. Oxidation states of transition metals in undoped and doped NCM-622 with Zr. Reprinted from [96].

The $\mathrm{Zr}$-doped material exhibits improved performance at higher cycling rates and a more stable capacity over 50 galvanostatic cycles (Figure 14). The improved rate capability is reflected in the impedance behavior with the Zr-doped NCM622, demonstrating responses that are lower by an order of magnitude and less impedance growth during cycling.

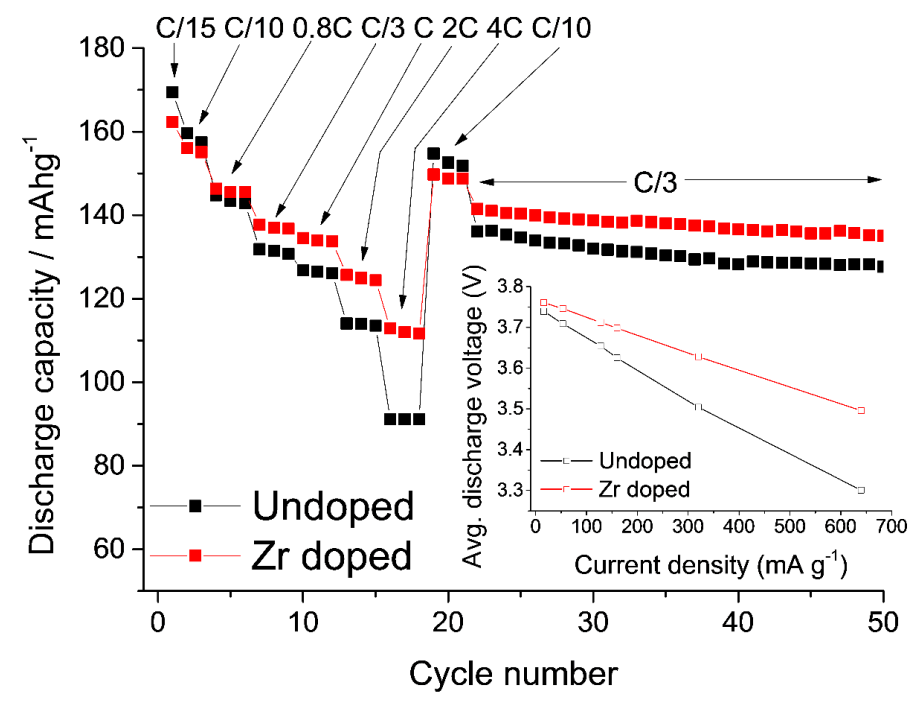

Figure 14. Galvanostatic cycling of $\mathrm{LiNi}_{0.6} \mathrm{Co}_{0.2} \mathrm{Mn}_{0.2} \mathrm{O}_{2}$ and $\mathrm{LiNi}_{0.54} \mathrm{Zr}_{0.04} \mathrm{Co}_{0.2} \mathrm{Mn}_{0.2} \mathrm{O}_{2}$ under various $\mathrm{C}$ rates at $45^{\circ} \mathrm{C}\left(1 \mathrm{C}\right.$ rate: $\left.160 \mathrm{mAh} \cdot \mathrm{g}^{-1}\right)$. Reprinted from [96]. 
Post-cycling analysis by TEM and electron-diffraction studies after 50 cycles of the undoped NCM622 reveal the presence of a spinel-like phase on the surface of the particles (Figure 15a-c). Spinel formation is considered an intermediate step towards the formation of electrochemically inactive rock salt [102]. Among several investigated particles of Zr-doped NCM622, no evidence for spinel formation was found (Figure $15 \mathrm{~d}-\mathrm{f}$ ). Some particles show reflections indicative of $\mathrm{Li}_{2} \mathrm{ZrO}_{3}$, showcasing the formation of lithium-rich phases on the particles with excess lithium.

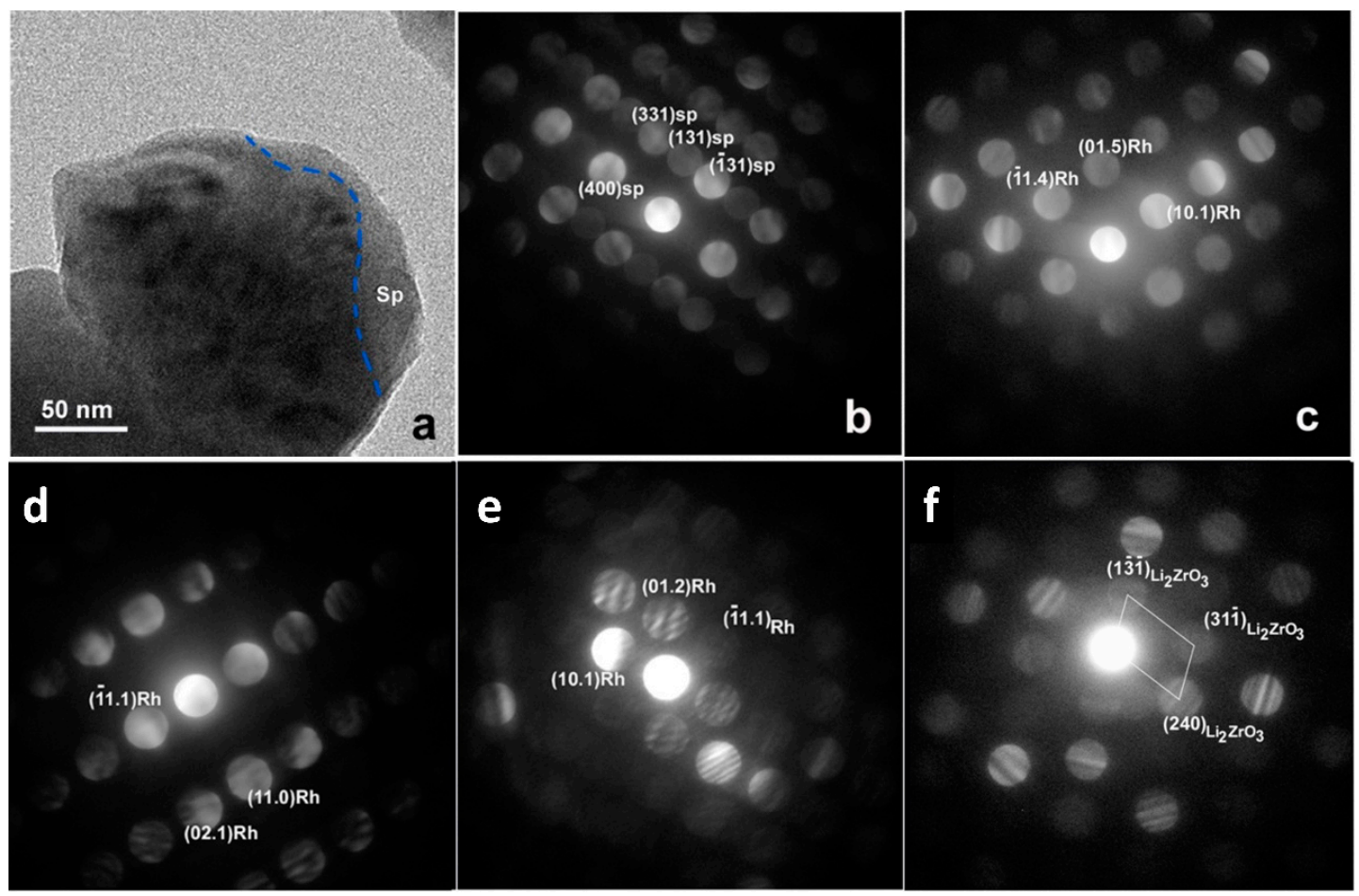

Figure 15. (a-c) TEM image and electron diffraction patterns of undoped NCM622 after 50 cycles at $45{ }^{\circ} \mathrm{C}$. Spinel-like structure species were found on the surface; $(\mathbf{d}-\mathbf{f})$ Electron-diffraction patterns of Zr-doped NCM622 after 50 cycles at $45{ }^{\circ} \mathrm{C}$. No indication of spinel was found, among several investigated particles. The formation of $\mathrm{Li}_{2} \mathrm{ZrO}_{3}$ was confirmed in small amounts. Reprinted from [96].

Another study was dedicated to investigating the impact of minor aluminum doping (0.01 at \%) of the NCM523 material prepared at BASF [97]. According to the synthetic procedure, Al doping took place at the expense of all the transition metals (Ni, Co, Mn). An important motivating factor in this research was to understand the preference of $\mathrm{Al}$ doping at $\mathrm{Mn}$, Co or Ni sites, a question which may be addressed by theoretical calculation of the substitution energies. These were calculated for the configurations doped at the preferred $\mathrm{Co}, \mathrm{Mn}$ and $\mathrm{Ni}$ sites as $-5.13-3.10$ and $-5.86 \mathrm{eV}$, respectively. Since the highest negative substitution energy of $\mathrm{Al}$ is at the $\mathrm{Ni}$ sites, $\mathrm{Al}$ substitution is preferred there rather than at the Co sites. The thermodynamic preference of $\mathrm{Al}^{3+}$ substitutions follows the order $\mathrm{Ni}$ $>\mathrm{Co}>\mathrm{Mn}$. The local magnetic moments of undoped $\mathrm{LiNi}_{0.5} \mathrm{Co}_{0.2} \mathrm{Mn}_{0.3} \mathrm{O}_{2}$ suggest that the formal charges on $\mathrm{Co}$ and $\mathrm{Mn}$ are +3 and +4 , respectively. It follows from our calculations that both $\mathrm{Ni}^{2+}$ (magnetic moment $\sim 1.5$ ) and $\mathrm{Ni}^{3+}$ (magnetic moment $\sim 0.8$ ) ions exist in both Al-doped and undoped pristine materials.

Since the NCM523 cathode material is much less problematic (due to a lower Ni-content) than Li-rich NCM622 and NCM811, improvement in the electrochemical performance is usually less obvious. Nonetheless, it was shown that by adding 0.01 at \% of Al-dopant to the material, the electrodes demonstrate lower capacity fading (Figure 16). 

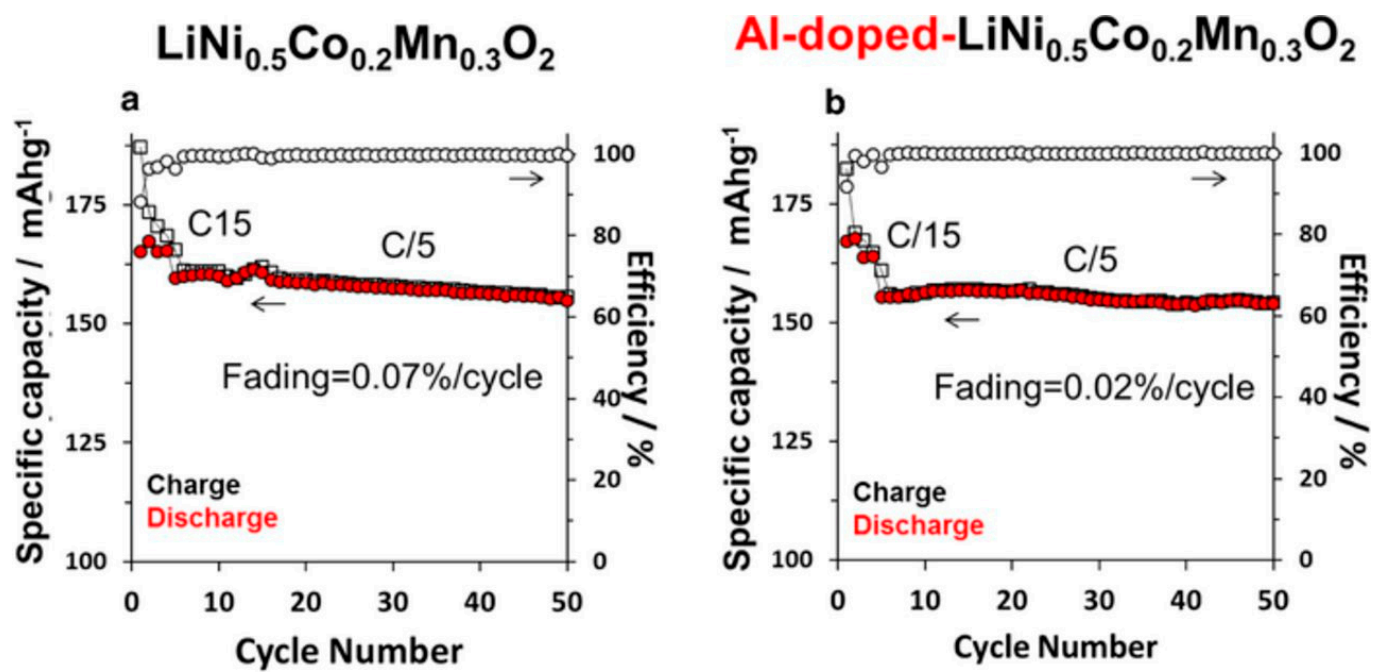

Figure 16. Cycle stability of NCM523 (a) and Al-doped NCM523 (b) at $30{ }^{\circ} \mathrm{C}$. The cycling rate was C/15 for the initial cycles and C/5 for the rest. Reprinted from [97].

Interestingly, lower charge transfer and surface-film resistance were measured for the doped material after cycling and aging at $30{ }^{\circ} \mathrm{C}$. This effect is attributed, to some extent, to the formation of $\mathrm{LiAlO}_{2}$ and other species on the surface of the NCM particles. We suggest that a more stable cathode/solution interface and, consequently, lower surface-film and charge-transfer resistance will result from specific surface interactions of these electrodes with solution species. We also suggest that upon cycling or aging in the solutions, a thin reactive surface layer (RSL) on the particles of the Al-doped material becomes enriched with $\mathrm{Al}^{3+}$-ions, which initiate interfacial reactions, such as:

$$
\begin{gathered}
\mathrm{Al}^{3+}+\mathrm{Li}^{+}+4 \mathrm{HF} \rightarrow \mathrm{LiAlF}_{4}(\mathrm{~s}) \downarrow+4 \mathrm{H}^{+} \\
\mathrm{Al}^{3+}+\mathrm{Li}^{+}+\mathrm{Ni}^{2+}+3 \mathrm{H}_{2} \mathrm{O} \rightarrow \mathrm{LiNiAlO}_{3}(\mathrm{~s}) \downarrow+6 \mathrm{H}^{+} \\
\mathrm{Al}^{3+}+\mathrm{Li}^{+}+2 \mathrm{H}_{2} \mathrm{O} \rightarrow \mathrm{LiAlO}_{2}(\mathrm{~s}) \downarrow+4 \mathrm{H}^{+}
\end{gathered}
$$

It is reasonable to propose that Al-containing species that form in an RSL upon cycling or aging in solutions of Al-doped electrodes may partially suppress the unavoidable formation of $\mathrm{LiF}$, stabilizing the electrode/solution interface and, hence, leading to lower impedance and more stable charge/discharge behavior of these electrodes. Thus, the modified interface comprising the $\mathrm{Li}^{+}$-ion conducting active centers such as $\mathrm{LiAlO}_{2}, \mathrm{AlF}_{3}, \mathrm{Li}\left[\mathrm{AlF}_{4}\right]$ and others may promote enhanced $\mathrm{Li}^{+}$ transport to the electrode bulk and facilitate the charge-transfer reactions [104].

The higher thermal stability of the Al-doped samples was reflected by the DSC responses of electrodes in the charged state $(4.3 \mathrm{~V})$. The heat evolved was calculated as 575 and $520 \mathrm{~J} \cdot \mathrm{g}^{-1}$ for undoped NCM523 and Al-doped NCM523, respectively. Since safety is a major concern for commercial application, high capacity materials must be low in heat release. This is especially important for electric-vehicle battery cells of several ampere hours per cell. A failure in one cell can potentially be catastrophic for the whole battery pack. In a recent study by Cho et al., NCM433, NCM523, NCM622 and NCM811 were investigated in terms of thermal stability under charged conditions [105]. The nickel-rich materials NCM811 and NCM622 showed onset temperatures of $\sim 150$ and $200{ }^{\circ} \mathrm{C}$, respectively (Figure 17). Critical failure is accompanied by phase changes from layered to spinel and finally to rock salt. All steps involve gas evolution, which resulted in pressure inside the cell. It is clear that the high capacity and energy of NCM811 is also problematic, and efforts have to be made to ensure sufficient thermal stability by doping and coating approaches. 

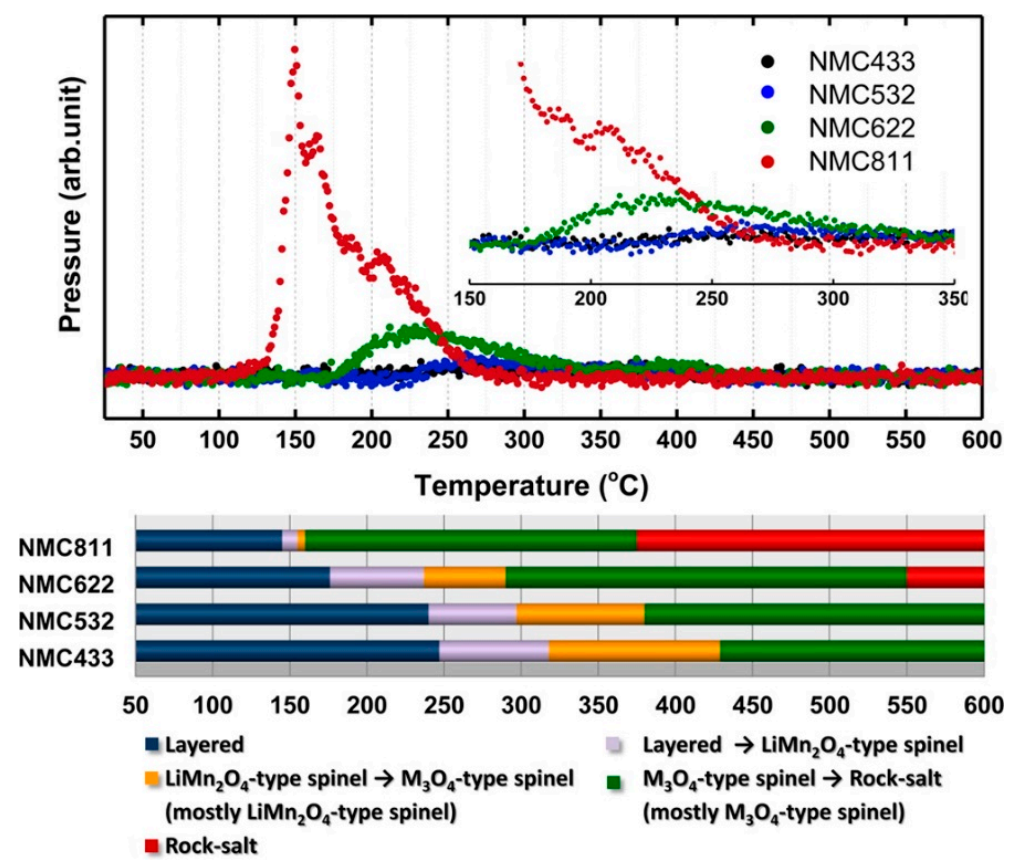

Figure 17. Pressure diagram for NCM433, NCM523, NCM622 and NCM811 electrodes over a wide temperature range and the accompanying phase changes; all measurements were made for charged materials without any addition of electrolyte solution. Reprinted from [105].

The increase in the nickel content in NCMs from NCM333 to NCM811 leads to an increase in capacity from $\sim 155$ to $195 \mathrm{mAh} \cdot \mathrm{g}^{-1}$. The higher delithiation degree in NCM811 ( 70\%) is substantial and leads to multiple phase changes during charge and discharge $[28,106]$. Depletion of the lithium layer is accompanied by a deshielding of the oxygen layers since less and less lithium ions are present. This leads to a stronger repulsive force and hence to an expansion of the $c$-lattice parameter. With further lithium removal, the emptier lithium layer is likely to be partially filled with transition metals (e.g., Ni) to stabilize the lattice. This leads to strong interactions between high-oxidation-state transition metals inside the lithium layer and the oxygen layers, eventually lowering the $c$-parameter again (Figure 18). The overall volume change in NCM811 is $\sim 5 \%$ if charged to $4.3 \mathrm{~V}$ [28]. The rapid c-parameter contraction, starting from $4.1 \mathrm{~V}$, results in a fast volume change of $\sim 2.5 \%$ and stress on the phase boundaries of the primary particles. NCM811 and NCM622 are known to form microcracks along the phase boundaries during cycling, leading to an increase in surface areas for side reactions [42].

It should be emphasized that the formation of a reactive surface layer enriched with $\mathrm{Al}^{3+}$ dopant ions, as proposed above, is very important for understanding electrode cycling behavior. This is due to the fact that in the charged electrode some nucleation may be induced starting in RSL to promote the transformation of a layered structure toward a spinel-type structure. This reactive surface layer can also be represented as a "disordered surface layer" surrounding the core of nanoparticles or microparticles of cathode layered-structure materials. It was demonstrated, for instance, that for Li-rich electrodes comprising nano- $\mathrm{Li}_{2} \mathrm{MnO}_{3}$ particles, the isothermal magnetization profiles measured by magnetic susceptibility do not differ upon aging the material in EC-DMC/ $\mathrm{LiPF}_{6}$ solution, indicating that magnetic transition does not occur (Figure S8) [107]. A decrease in the magnetic moment of the aged nanoparticles shown in Table S2 corresponds to an increase in the reciprocal magnetic susceptibility due to the presence of $\mathrm{Mn}$ ions in the low-spin state in a thin disordered layer at the surface of $\mathrm{Li}_{2} \mathrm{MnO}_{3}$ particles. This implies that manganese ions are present in a lower oxidation state than 4+: either $\mathrm{Mn}^{3+}(S=1)$ or $\mathrm{Mn}^{2+}\left(S=\frac{1}{2}\right)$. Magnetic susceptibility tests have been employed to estimate the amount of these ions [107]. On the basis of the proposed disordered surface layer (DSL) model, it was possible to explain the origin of the observed electrochemical activity of nano- $\mathrm{Li}_{2} \mathrm{MnO}_{3}$ 
electrodes at 4.0-4.1 $\mathrm{V}$ that is likely due to reversible oxidation/reduction of $\mathrm{Mn}^{3+}$ and $\mathrm{Mn}^{2+}$ ions from nanoparticles $(20-30 \mathrm{~nm}$ ) with the disordered surface layers of 3-4 $\mathrm{nm}$. The volume of the DSL was estimated to reach $\sim 85 \%-60 \%$, respective to the total volume of the nanoparticle. One of the main conclusions from this work [107] was that the partial transition of layered $\mathrm{Li}_{2} \mathrm{MnO}_{3}$ to a spinel-type structure (confirmed by analysis of XRD, TEM, and Raman spectroscopy studies) occurred in these systems during delithiation/lithiation.

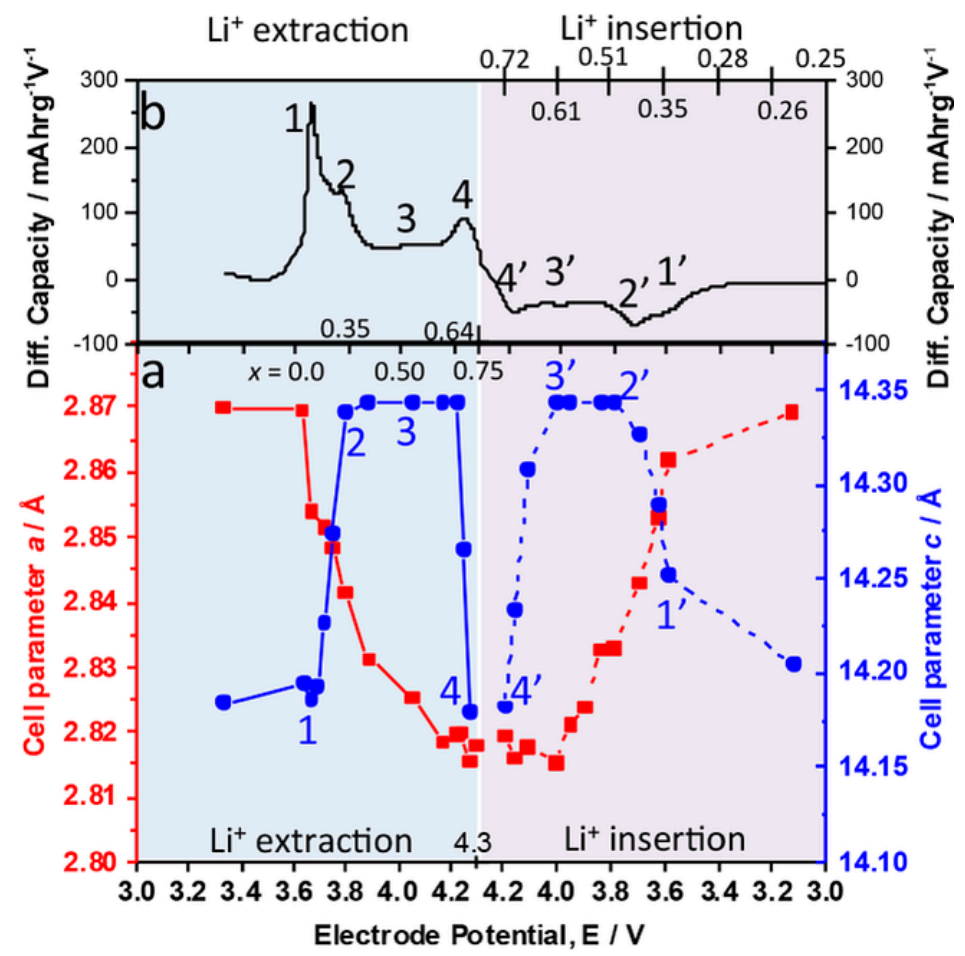

Figure 18. (a) Lattice parameter changes in NCM811 electrode during charge and discharge measured by in situ XRD; (b) $\mathrm{d} Q / \mathrm{d} V$ profile for NCM811. Reprinted with permission [106]. Copyright 2015, Wiley.

\subsection{Surface Coatings of $\mathrm{Li}\left[\mathrm{Ni}_{x} \mathrm{Co}_{y} \mathrm{Mn} n_{z}\right] \mathrm{O}_{2}$ Materials}

Set aside from doping strategies, coating cathode materials with thin surface layers is a popular approach to enhance the cycle life and thermal stability of electrodes. The objective is to protect the surface area of the active material by an inert thin layer of organic or inorganic compounds. The coating will act as a barrier between the active material and the electrolyte, minimizing parasitic side reactions at high voltages. In addition, some coatings are known to be HF scavengers, which is especially beneficial if the coating is not uniform or tends to break during cycling [108]. Most of the reported coating strategies employ a wet chemical approach to deposit the coating layer onto the active material, followed by a heat treatment. While this approach is fairly easy to perform, the coatings often suffer from cracks or are deposited as flakes. Recently, powder atomic layer deposition (pALD) was shown to be an alternative technique with several benefits [109]. The coating thickness can be tailored just by the number of pALD cycles and, furthermore, the coating is uniform amongst all secondary particles. An inherent drawback is the still higher cost of the pALD technique.

Numerous coatings have been investigated for different NCMs (e.g., $\mathrm{AlF}_{3}$ [104], $\mathrm{Al}_{2} \mathrm{O}_{3}$ [47], $\mathrm{ZrO}_{2}$ [110], $\mathrm{TiO}_{2}$ [111,112], $\mathrm{SiO}_{2}$ [113]). All the coatings were shown to improve the cycle stability of the investigated active material when used in low amounts (Figure 19A). The coatings do not contribute to the electrode capacity, and hence high amounts will lower the specific capacity of the active material [47]. Since side reactions are minimal in coated samples, a lower impedance growth 
during cycling is usually observed in coated active materials. A $1 \mathrm{wt} \% \mathrm{TiO}_{2}$ coating on $\mathrm{NCM} 622$ was shown to limit the impedance to $55 \Omega$ in the coated versus $70 \Omega$ in the bare NCM622 after 50 cycles at $30{ }^{\circ} \mathrm{C}$ (Figure 19B) [111].
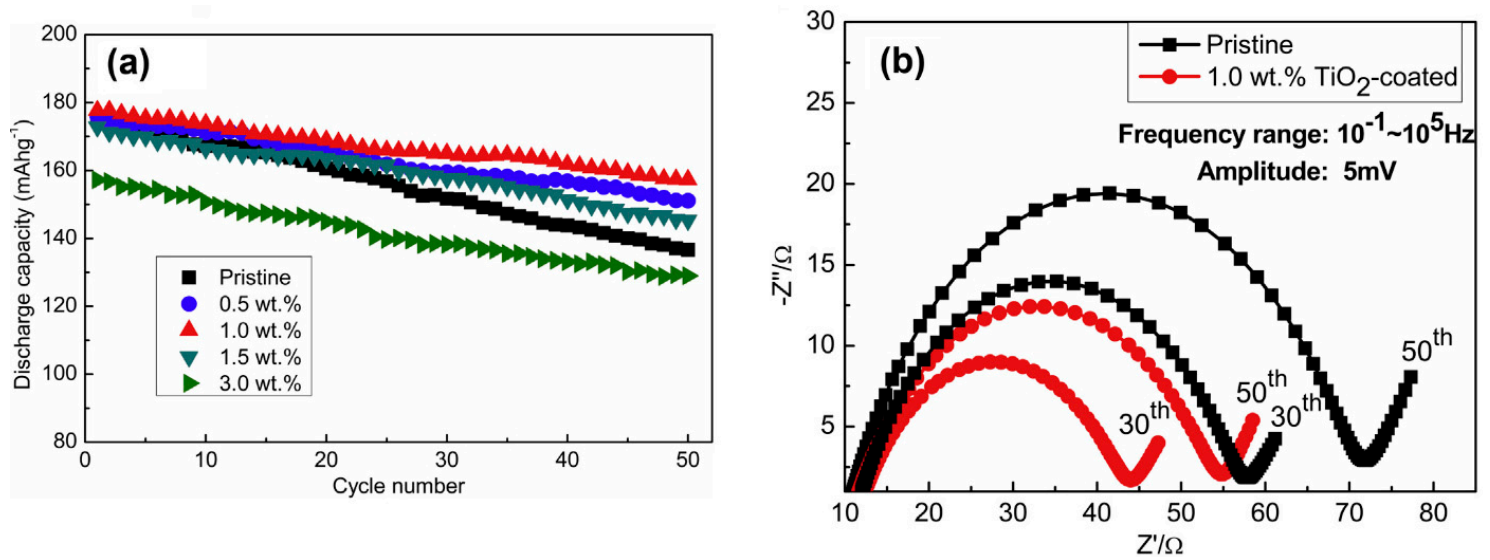

Figure 19. (a) Cycle stability of NCM622 material coated with various amounts of $\mathrm{TiO}_{2}$ at $30{ }^{\circ} \mathrm{C}$, cycled in the potential range of 3-4.5 V; (b) Impedance spectra for pristine and $1 \mathrm{wt} \% \mathrm{TiO}_{2}$-coated NCM622 after 30 and 50 cycles. Reprinted with permission [111]. Copyright 2014, Elsevier.

Another property targeted by coatings is the thermal stability of the active material, especially of nickel-rich NCMs. The onset temperature of charged NCM622 (4.3 V) was measured to be $\sim 290{ }^{\circ} \mathrm{C}$, while a $0.5 \mathrm{wt} \% \mathrm{SiO}_{2}$ coating could lower the onset to $\sim 270{ }^{\circ} \mathrm{C}$ (Figure 20) [113]. It must be emphasized that DSC measurements of charged samples are often run with dry powder, but a more realistic picture would need the addition of the electrolyte solution as well [16]. Nonetheless, trends can also be observed from measurements on dry powder.

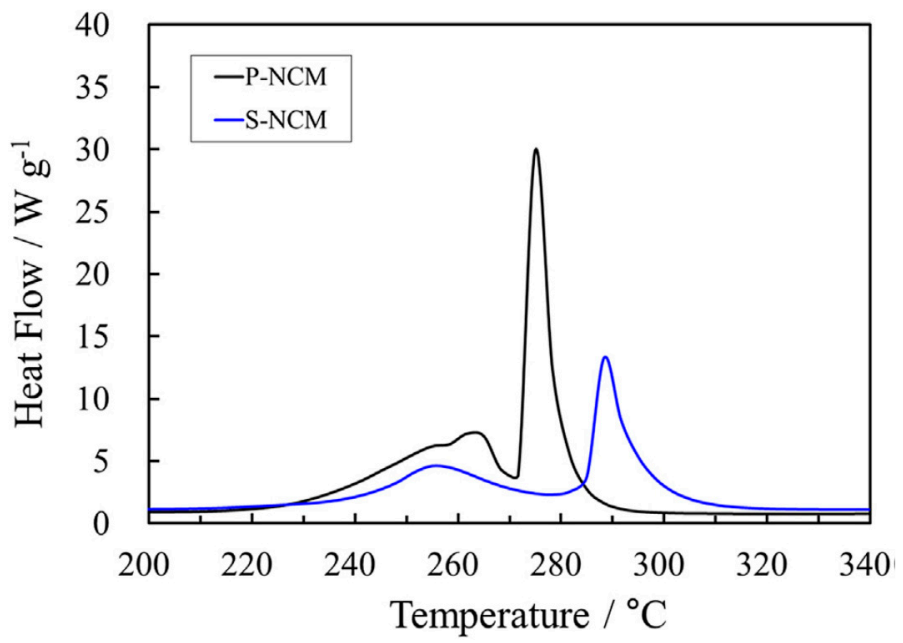

Figure 20. DSC measurement of charged pristine NCM622 (P-NCM) and $0.5 \mathrm{wt} \% \mathrm{SiO}_{2}$-coated NCM622 (S-NCM) charged to 4.3 V. Reprinted with permission [113]. Copyright 2015, Elsevier.

\section{Conclusions}

This paper is a review of recent advances and challenges in the field of materials for positive electrodes (cathodes) of lithium-ion batteries. We focused on two main groups of materials, namely: (1) $\mathrm{Li}$ and Mn-rich layered composites of the general formula $x \mathrm{Li}_{2} \mathrm{MnO}_{3} \cdot(1-x) \mathrm{Li}\left[\mathrm{Ni}_{a} \mathrm{Co}_{b} \mathrm{Mn}_{c}\right] \mathrm{O}_{2}$ $(a+b+c=1)$ that are usually described as comprising two layered structure phases of $\mathrm{Li}_{2} \mathrm{MnO}_{3}$ 
and $\mathrm{Li}\left[\mathrm{Ni}_{a} \mathrm{Co}_{b} \mathrm{Mn}_{c}\right] \mathrm{O}_{2}(a+b+c=1)$ integrated on atomic level and existing side by side in the composite, and (2) lithiated transition metal oxides comprising $\mathrm{Ni}, \mathrm{Co}$, and $\mathrm{Mn}$ and known as $\mathrm{Ni}$-rich $\mathrm{Li}\left[\mathrm{Ni}_{x} \mathrm{Co}_{y} \mathrm{Mn}_{z}\right] \mathrm{O}_{2}$ layered structure materials (NCM, $x>0.5, x+y+z=1$ ). Attention was paid to the advantages and drawbacks of the above materials as cathodes in LIBs (especially for EV-applications). It was concluded that during the last decade, the main focus of many research groups has been on modifications of these materials; lattice doping by foreign cations (for instance, $\mathrm{Mg}^{2+}, \mathrm{Al}^{3+}, \mathrm{Zr}^{4+}$ ) and thin surface coatings (for instance, prepared by ALD). From numerous literature reports reviewed in this paper, it was established that these modifications resulted in substantial improvement of electrodes' cycling behavior such as decreasing the capacity fading and the stabilization of the average voltage. Surface coatings also lead to reducing side reactions of cathodes with solution species as well as to increasing their thermal stability in charged states. We also concluded that the fabrication of nanostructured cathode materials with well-defined morphologies, such as porous structures and hollow spheres, is another interesting approach in the field of LIB.

Due to the ever-growing interest of academic researchers and industrial groups in advanced materials for high-energy LIBs, the authors of the present review believe that it will stimulate further investigations in broad aspects related to materials science, electrochemistry, and thermal studies, etc.

Supplementary Materials: The following are available online at www.mdpi.com/2304-6740/5/2/32/s1, Table S1. Literature Survey of Li- and Mn-Rich Porous Cathode Materials for LIBs. Table S2. Magnetic properties of the pristine and two-week aged (in $\mathrm{EC}-\mathrm{DMC} / \mathrm{LiPF}_{6}$ solution) $\mathrm{Li}_{2} \mathrm{MnO}_{3}$ nanostructured samples. Figure S1. A comparison between the capacity, voltage and energy fade of Ni-rich and Li- and $\mathrm{Mn}$-rich materials. Figure S2. XRD pattern of the cycled $x \mathrm{Li}_{2} \mathrm{MnO}_{3} \cdot(1-x) \mathrm{Li}\left[\mathrm{Mn}_{y} \mathrm{Ni}_{z} \mathrm{Co}_{w}\right] \mathrm{O}_{2} / \mathrm{AlF}_{3}$ material. Figure S3. Schematic view of constructing hybrid surface layers consisting of reduced graphene oxide (rGO) and chemically activated phase on cathode materials. Figure S4. Voltage profiles of PS and HGO cathodes; Rate capabilities measured with increasing C-rates; Cycling performance during 100 cycles. Figure S5. XRD patterns and Rietveld analysis plots of $\mathrm{Li}_{1.2} \mathrm{Ni}_{0.16} \mathrm{Mn}_{0.56-x} \mathrm{Mg}_{x} \mathrm{Co}_{0.08} \mathrm{O}_{2}$. Figure S6. Discharge capacities of electrodes comprising $\mathrm{Li}, \mathrm{Mn}$-rich $\mathrm{Li}_{1.2} \mathrm{Ni}_{0.13} \mathrm{Mn}_{0.54} \mathrm{Co}_{0.13} \mathrm{O}_{2}$ material prepared by hydrothermal method and $\mathrm{Li}_{1.165} \mathrm{Mn}_{0.501} \mathrm{Ni}_{0.167} \mathrm{Co}_{0.167} \mathrm{O}_{2}$ (LMNCO) material prepared by ultrasonic-assisted co-precipitation method. Figure S7. Schematic diagram of the synthesis of porous $\mathrm{Li}_{1.2} \mathrm{Ni}_{0.13} \mathrm{Co}_{0.13} \mathrm{Mn}_{0.54} \mathrm{O}_{2}$ (LNCMO) material; The initial charge-discharge curves of the first cycle and rate capability of porous $\mathrm{Li}_{1.2} \mathrm{Ni}_{0.13} \mathrm{Co}_{0.13} \mathrm{Mn}_{0.54} \mathrm{O}_{2}$ and bulk $\mathrm{Li}_{1.2} \mathrm{Ni}_{0.13} \mathrm{Co}_{0.13} \mathrm{Mn}_{0.54} \mathrm{O}_{2}$ electrode materials. Figure S8. Plot of the reciprocal magnetic susceptibility $\mathrm{H} / \mathrm{M}$ of the pristine and two-week aged $\mathrm{Li}_{2} \mathrm{MnO}_{3}$ nanostructured powders.

Conflicts of Interest: The authors declare no conflict of interest.

\section{References}

1. Goodenough, J.B.; Park, K.-S. The Li-ion rechargeable battery: A perspective. J. Am. Chem. Soc. 2013, 135, 1167-1176. [CrossRef] [PubMed]

2. Etacheri, V.; Marom, R.; Elazari, R.; Salitra, G.; Aurbach, D. Challenges in the development of advanced Li-ion batteries: A review. Energy Environ. Sci. 2011, 4, 3243-3262. [CrossRef]

3. Manthiram, A. Materials challenges and opportunities of lithium ion batteries. J. Phys. Chem. Lett. 2011, 2, 176-184. [CrossRef]

4. Armand, M.; Tarascon, J.-M. Building better batteries. Nature 2008, 451, 652-657. [CrossRef] [PubMed]

5. Thackeray, M.M.; Johnson, C.S.; Vaughey, J.T.; Li, N.; Hackney, S.A. Advances in manganese-oxide 'composite' electrodes for lithium-ion batteries. J. Mater. Chem. 2005, 15, 2257-2267. [CrossRef]

6. Erickson, E.M.; Ghanty, C.; Aurbach, D. New horizons for conventional lithium ion battery technology. J. Phys. Chem. Lett. 2014, 5, 3313-3324. [CrossRef] [PubMed]

7. Berg, E.J.; Villevieille, C.; Streich, D.; Trabesinger, S.; Novak, P. Rechargeable batteries: Grasping for the limits of chemistry. J. Electrochem. Soc. 2015, 162, A2468-A2475. [CrossRef]

8. Yan, J.H.; Liu, X.B.; Li, B.Y. Recent progress in Li-rich layered oxides as cathode materials for Li-ion batteries. RSC Adv. 2014, 4, 63268-63284. [CrossRef]

9. Amalraj, F.; Talianker, M.; Markovsky, B.; Sharon, D.; Burlaka, L.; Shafir, G.; Zinigrad, E.; Haik, O.; Aurbach, D.; Lampert, J.; et al. Study of the lithium-rich integrated compound $x \mathrm{Li}_{2} \mathrm{MnO}_{3} \cdot(1-x) \mathrm{LiMO}_{2}$ ( $x$ around $0.5 ; \mathrm{M}=\mathrm{Mn}, \mathrm{Ni}, \mathrm{Co} ; 2: 2: 1$ ) and its electrochemical activity as positive electrode in lithium cells. J. Electrochem. Soc. 2012, 160, A324-A337. 
10. Mohanty, D.; Kalnaus, S.; Meisner, R.A.; Rhodes, K.J.; Li, J.L.; Payzant, E.A.; Wood, D.L.; Daniel, C. Structural transformation of a lithium-rich $\mathrm{Li}_{1.2} \mathrm{Co}_{0.1} \mathrm{Mn}_{0.55} \mathrm{Ni}_{0.15} \mathrm{O}_{2}$ cathode during high voltage cycling resolved by in situ X-ray diffraction. J. Power Sources 2013, 229, 239-248.

11. Boulineau, A.; Croguennec, L.; Delmas, C.; Weill, F. Structure of $\mathrm{Li}_{2} \mathrm{MnO}_{3}$ with different degrees of defects. Solid State Ion. 2010, 180, 1652-1659. [CrossRef]

12. Shunmugasundaram, R.; Arumugam, R.S.; Dahn, J.R. A study of stacking faults and superlattice ordering in some Li-rich layered transition metal oxide positive electrode materials. J. Electrochem. Soc. 2016, 163, A1394-A1400. [CrossRef]

13. Shukla, A.K.; Ramasse, Q.M.; Ophus, C.; Duncan, H.; Hage, F.; Chen, G. Unravelling structural ambiguities in lithium- and manganese-rich transition metal oxides. Nat Commun. 2015, 6. [CrossRef] [PubMed]

14. Yu, X.; Lyu, Y.; Gu, L.; Wu, H.; Bak, S.-M.; Zhou, Y.; Amine, K.; Ehrlich, S.N.; Li, H.; Nam, K.-W.; et al. Understanding the rate capability of high-energy-density Li-rich layered $\mathrm{Li}_{1.2} \mathrm{Ni}_{0.15} \mathrm{Co}_{0.1} \mathrm{Mn}_{0.55} \mathrm{O}_{2}$ cathode materials. Adv. Energy Mater. 2014, 4, 1300950-n/a.

15. Long, B.R.; Croy, J.R.; Dogan, F.; Suchomel, M.R.; Key, B.; Wen, J.; Miller, D.J.; Thackeray, M.M.; Balasubramanian, M. Effect of cooling rates on phase separation in $0.5 \mathrm{Li}_{2} \mathrm{MnO}_{3} \cdot 0.5 \mathrm{LiCoO}_{2}$ electrode materials for Li-ion batteries. Chem. Mater. 2014, 26, 3565-3572.

16. Amalraj, F.; Talianker, M.; Markovsky, B.; Burlaka, L.; Leifer, N.; Goobes, G.; Erickson, E.M.; Haik, O.; Grinblat, J.; Zinigrad, E.; et al. Studies of $\mathrm{Li}$ and $\mathrm{Mn}$-rich $\mathrm{Li}_{x}[\mathrm{MnNiCo}] \mathrm{O}_{2}$ electrodes: Electrochemical performance, structure, and the effect of the aluminum fluoride coating. J. Electrochem. Soc. 2013, 160, A2220-A2233. [CrossRef]

17. Liu, Z.; Yu, A.; Lee, J.Y. Synthesis and characterization of $\mathrm{LiNi}_{1-x-y} \mathrm{Co}_{x} \mathrm{Mn}_{y} \mathrm{O}_{2}$ as the cathode materials of secondary lithium batteries. J. Power Sources 1999, 81-82, 416-419.

18. Yabuuchi, N.; Ohzuku, T. Novel lithium insertion material of $\mathrm{LiCo}_{1 / 3} \mathrm{Ni}_{1 / 3} \mathrm{Mn}_{1 / 3} \mathrm{O}_{2}$ for advanced lithium-ion batteries. J. Power Sources 2003, 119, 171-174. [CrossRef]

19. Ohzuku, T.; Makimura, Y. Layered lithium insertion material of $\mathrm{LiCo}_{1 / 3} \mathrm{Ni}_{1 / 3} \mathrm{Mn}_{1 / 3} \mathrm{O}_{2}$ for lithium-ion batteries. Chem. Lett. 2001, 30, 642-643. [CrossRef]

20. Yabuuchi, N.; Makimura, Y.; Ohzuku, T. Solid-state chemistry and electrochemistry of $\mathrm{LiCo}_{1 / 3} \mathrm{Ni}_{1 / 3} \mathrm{Mn}_{1 / 3} \mathrm{O}_{2}$ for advanced lithium-ion batteries: III. Rechargeable capacity and cycleability. J. Electrochem. Soc. 2007, 154, A314-A321. [CrossRef]

21. Kang, S.H.; Johnson, C.S.; Vaughey, J.T.; Amine, K.; Thackeray, M.M. The effects of acid treatment on the electrochemical properties of $0.5 \mathrm{Li}_{2} \mathrm{MnO}_{3} \cdot 0.5 \mathrm{LiNi}_{0.44} \mathrm{Co}_{0.25} \mathrm{Mn}_{0.31} \mathrm{O}_{2}$ electrodes in lithium cells. J. Electrochem. Soc. 2006, 153, A1186-A1192.

22. Rossouw, M.H.; Thackeray, M.M. Lithium manganese oxides from $\mathrm{Li}_{2} \mathrm{MnO}_{3}$ for rechargeable lithium battery applications. Mater. Res. Bull. 1991, 26, 463-473. [CrossRef]

23. Kalyani, P.; Chitra, S.; Mohan, T.; Gopukumar, S. Lithium metal rechargeable cells using $\mathrm{Li}_{2} \mathrm{MnO}_{3}$ as the positive electrode. J. Power Sources 1999, 80, 103-106. [CrossRef]

24. Lu, Z.H.; MacNeil, D.D.; Dahn, J.R. Layered cathode materials $\operatorname{Li}\left(\mathrm{Ni}_{x} \operatorname{Li}_{(1 / 3-2 x / 3)} \operatorname{Mn}_{(2 / 3-x / 3)}\right) \mathrm{O}_{2}$ for lithium-ion batteries. Electrochem. Solid State Lett. 2001, 4, A191-A194. [CrossRef]

25. Koga, H.; Croguennec, L.; Menetrier, M.; Mannessiez, P.; Weill, F.; Delmas, C.; Belin, S. Operando $\mathrm{X}$-ray absorption study of the redox processes involved upon cycling of the Li-rich layered oxide $\mathrm{Li}_{1.20} \mathrm{Mn}_{0.54} \mathrm{Co}_{0.13} \mathrm{Ni}_{0.13} \mathrm{O}_{2}$ in li ion batteries. J. Phys. Chem. C 2014, 118, 5700-5709.

26. Kim, T.; Song, B.H.; Lunt, A.J.G.; Cibin, G.; Dent, A.J.; Lu, L.; Korsunsky, A.M. In operando x-ray absorption spectroscopy study of charge rate effects on the atomic environment in graphene-coated Li-rich mixed oxide cathode. Mater. Des. 2016, 98, 231-242. [CrossRef]

27. Fell, C.R.; Chi, M.; Meng, Y.S.; Jones, J.L. In situ x-ray diffraction study of the lithium excess layered oxide compound $\mathrm{Li}\left[\mathrm{Li}_{0.2} \mathrm{Ni}_{0.2} \mathrm{Mn}_{0.6}\right] \mathrm{O}_{2}$ during electrochemical cycling. Solid State Ion. 2012, 207, 44-49.

28. Li, J.; Shunmugasundaram, R.; Doig, R.; Dahn, J.R. In situ x-ray diffraction study of layered Li-Ni-Mn-Co oxides: Effect of particle size and structural stability of core-shell materials. Chem. Mater. 2016, 28, 162-171. [CrossRef]

29. Abe, M.; Matsumoto, F.; Saito, M.; Yamamura, H.; Kobayashi, G.; Ito, A.; Sanada, T.; Hatano, M.; Ohsawa, Y.; Sato, Y. Activation of a Li-rich solid-solution layered $\mathrm{LiNi}_{0.18} \mathrm{Li}_{0.20} \mathrm{Co}_{0.03} \mathrm{Mn}_{0.58} \mathrm{O}_{2}$ cathode and retention of high capacities via an electrochemical pretreatment with a low discharge voltage limit. Chem. Lett. 2012, 41, 418-419. 
30. Zheng, J.M.; Xu, P.H.; Gu, M.; Xiao, J.; Browning, N.D.; Yan, P.F.; Wang, C.M.; Zhang, J.G. Structural and chemical evolution of Li- and Mn-rich layered cathode material. Chem. Mater. 2015, 27, 1381-1390. [CrossRef]

31. Nayak, P.K.; Grinblat, J.; Levi, E.; Markovsky, B.; Aurbach, D. Effect of cycling conditions on the electrochemical performance of high capacity Li and Mn-rich cathodes for Li-ion batteries. J. Power Sources 2016, 318, 9-17. [CrossRef]

32. Rana, J.; Kloepsch, R.; Li, J.; Stan, M.; Schumacher, G.; Winter, M.; Banhart, J. Structural changes in a Li-rich $0.5 \mathrm{Li}_{2} \mathrm{MnO}_{3} \cdot 0.5 \mathrm{LiMn}_{0.4} \mathrm{Ni}_{0.4} \mathrm{Co}_{0.2} \mathrm{O}_{2}$ cathode material for Li-ion batteries: A local perspective. J. Electrochem. Soc. 2016, 163, A811-A820.

33. Rozier, P.; Tarascon, J.M. Review-Li-rich layered oxide cathodes for next-generation Li-ion batteries: Chances and challenges. J. Electrochem. Soc. 2015, 162, A2490-A2499. [CrossRef]

34. Sathiya, M.; Rousse, G.; Ramesha, K.; Laisa, C.P.; Vezin, H.; Sougrati, M.T.; Doublet, M.L.; Foix, D.; Gonbeau, D.; Walker, W.; et al. Reversible anionic redox chemistry in high-capacity layered-oxide electrodes. Nat. Mater. 2013, 12, 827-835. [CrossRef] [PubMed]

35. McCalla, E.; Abakumov, A.M.; Saubanere, M.; Foix, D.; Berg, E.J.; Rousse, G.; Doublet, M.-L.; Gonbeau, D.; Novak, P.; Van Tendeloo, G.; et al. Visualization of O-O peroxo-like dimers in high-capacity layered oxides for Li-ion batteries. Science 2015, 350, 1516-1521. [CrossRef] [PubMed]

36. Saubanere, M.; McCalla, E.; Tarascon, J.M.; Doublet, M.L. The intriguing question of anionic redox in high-energy density cathodes for Li-ion batteries. Energy Environ. Sci. 2016, 9, 984-991. [CrossRef]

37. Armstrong, A.R.; Dupre, N.; Paterson, A.J.; Grey, C.P.; Bruce, P.G. Combined neutron diffraction, NMR, and electrochemical investigation of the layered-to-spinel transformation in $\mathrm{LiMnO}_{2}$. Chem. Mater. 2004, 16, 3106-3118. [CrossRef]

38. Gallagher, K.G.; Croy, J.R.; Balasubramanian, M.; Bettge, M.; Abraham, D.P.; Burrell, A.K.; Thackeray, M.M. Correlating hysteresis and voltage fade in lithium- and manganese-rich layered transition-metal oxide electrodes. Electrochem. Commun. 2013, 33, 96-98. [CrossRef]

39. Croy, J.R.; Gallagher, K.G.; Balasubramanian, M.; Long, B.R.; Thackeray, M.M. Quantifying hysteresis and voltage fade in $x \mathrm{Li}_{2} \mathrm{MnO}_{3} \cdot(1-\mathrm{x}) \mathrm{LiMn}_{0.5} \mathrm{Ni}_{0.5} \mathrm{O}_{2}$ electrodes as a function of $\mathrm{Li} 2 \mathrm{MnO} 3$ content. J. Electrochem. Soc. 2014, 161, A318-A325.

40. Dogan, F.; Long, B.R.; Croy, J.R.; Gallagher, K.G.; Iddir, H.; Russell, J.T.; Balasubramanian, M.; Key, B. Re-entrant lithium local environments and defect driven electrochemistry of Li- and Mn-rich Li-ion battery cathodes. J. Am. Chem. Soc. 2015, 137, 2328-2335. [CrossRef] [PubMed]

41. Erickson, E.M.; Schipper, F.; Penki, T.R.; Shin, J.-Y.; Erk, C.; Chesneau, F.-F.; Markovsky, B.; Aurbach, D. Review-recent advances and remaining challenges for lithium ion battery cathodes: Li. Lithium-rich, $x \mathrm{Li}_{2} \mathrm{MnO}_{3} \cdot(1-x) \mathrm{LiNi}_{a} \mathrm{Co}_{b} \mathrm{Mn}_{c} \mathrm{O}_{2}$. J. Electrochem. Soc. 2017, 164, A6341-A6348. [CrossRef]

42. Schipper, F.; Erickson, E.M.; Erk, C.; Shin, J.-Y.; Chesneau, F.F.; Aurbach, D. Review-Recent advances and remaining challenges for lithium ion battery cathodes: I. Nickel-rich, $\mathrm{LiNi}_{x} \mathrm{Co}_{y} \mathrm{Mn}_{z} \mathrm{O}_{2}$. J. Electrochem. Soc. 2017, 164, A6220-A6228. [CrossRef]

43. Freire, M.; Kosova, N.; Jordy, C.; Chateigner, D.; Lebedev, O.; Maignan, A.; Pralong, V. A new active Li-Mn-O compound for high energy density Li-ion batteries. Nat. Mater. 2016, 15, 173-177. [CrossRef] [PubMed]

44. Thackeray, M.; Johnson, C.; Kim, J.-S.; Lauzze, K.; Vaughey, J.; Dietz, N.; Abraham, D.; Hackney, S.; Zeltner, W.; Anderson, M. $\mathrm{ZrO}_{2}$ and $\mathrm{Li}_{2} \mathrm{ZrO}_{3}$-stabilized spinel and layered electrodes for lithium batteries. Electrochem. Commun. 2003, 5, 752-758. [CrossRef]

45. Myung, S.-T.; Izumi, K.; Komaba, S.; Yashiro, H.; Bang, H.J.; Sun, Y.-K.; Kumagai, N. Functionality of oxide coating for $\mathrm{Li}\left[\mathrm{Li}_{0.05} \mathrm{Ni}_{0.4} \mathrm{Co}_{0.15} \mathrm{Mn}_{0.4}\right] \mathrm{O}_{2}$ as positive electrode materials for lithium-ion secondary batteries. J. Phys. Chem. C 2007, 111, 4061-4067.

46. Liu, J.; Manthiram, A. Functional surface modifications of a high capacity layered $\mathrm{Li}\left[\mathrm{Li}_{0.2} \mathrm{Mn}_{0.54} \mathrm{Ni}_{0.13} \mathrm{Co}_{0.13}\right] \mathrm{O}_{2}$ cathode. J. Mater. Chem. 2010, 20, 3961-3967.

47. Myung, S.-T.; Izumi, K.; Komaba, S.; Sun, Y.-K.; Yashiro, H.; Kumagai, N. Role of alumina coating on $\mathrm{Li}-\mathrm{Ni}-\mathrm{Co}-\mathrm{Mn}-\mathrm{O}$ particles as positive electrode material for lithium-ion batteries. Chem. Mater. 2005, 17, 3695-3704. [CrossRef]

48. Zheng, J.; Zhang, Z.; Wu, X.; Dong, Z.; Zhu, Z.; Yang, Y. The effects of ALF3 coating on the performance of $\mathrm{Li}\left[\mathrm{Li}_{0.2} \mathrm{Mn}_{0.54} \mathrm{Ni}_{0.13} \mathrm{Co}_{0.13}\right] \mathrm{O}_{2}$ positive electrode material for lithium-ion battery. J. Electrochem. Soc. 2008, 155, A775-A782. 
49. Yun, S.H.; Park, K.-S.; Park, Y.J. The electrochemical property of $\mathrm{ZrF}_{x}$-coated $\mathrm{Li}\left[\mathrm{Ni}_{1 / 3} \mathrm{Co}_{1 / 3} \mathrm{Mn}_{1 / 3}\right] \mathrm{O}_{2}$ cathode material. J. Power Sources 2010, 195, 6108-6115. [CrossRef]

50. Lee, H.; Kim, Y.; Hong, Y.-S.; Kim, Y.; Kim, M.G.; Shin, N.-S.; Cho, J. Structural characterization of the surface-modified $\mathrm{Li}_{\mathrm{x}} \mathrm{Ni}_{0.9} \mathrm{Co}_{0.1} \mathrm{O}_{2}$ cathode materials by $\mathrm{MPO} 4$ coating $(\mathrm{M}=\mathrm{Al}, \mathrm{Ce}, \mathrm{Sr}$, and $\mathrm{Fe}$ ) for $\mathrm{Li}$-ion cells. J. Electrochem. Soc. 2006, 153, A781-A786.

51. Sun, Y.K.; Lee, M.J.; Yoon, C.S.; Hassoun, J.; Amine, K.; Scrosati, B. The role of $\mathrm{AlF}_{3}$ coatings in improving electrochemical cycling of Li-enriched nickel-manganese oxide electrodes for Li-ion batteries. Adv. Mater. 2012, 24, 1192-1196. [CrossRef] [PubMed]

52. König, R.; Scholz, G.; Scheurell, K.; Heidemann, D.; Buchem, I.; Unger, W.E.S.; Kemnitz, E. Spectroscopic characterization of crystalline $\mathrm{AlF}_{3}$ phases. J. Fluor. Chem. 2010, 131, 91-97. [CrossRef]

53. Amalraj, S.F.; Markovsky, B.; Sharon, D.; Talianker, M.; Zinigrad, E.; Persky, R.; Haik, O.; Grinblat, J.; Lampert, J.; Schulz-Dobrick, M. Study of the electrochemical behavior of the "inactive" $\mathrm{Li}_{2} \mathrm{MnO}_{3}$. Electrochim. Acta 2012, 78, 32-39. [CrossRef]

54. Stechert, T.; Rushton, M.; Grimes, R.; Dillon, A. Predicted structure, thermo-mechanical properties and Li ion transport in $\mathrm{LiAlF}_{4}$ glass. J. Non Cryst. Solids 2012, 358, 1917-1923. [CrossRef]

55. Amalraj, F.; Kovacheva, D.; Talianker, M.; Zeiri, L.; Grinblat, J.; Leifer, N.; Goobes, G.; Markovsky, B.; Aurbach, D. Synthesis of integrated cathode materials $x \mathrm{Li}_{2} \mathrm{MnO}_{3} \cdot(1-x) \mathrm{LiMn}_{1 / 3} \mathrm{Ni}_{1 / 3} \mathrm{Co}_{1 / 3} \mathrm{O}_{2}(x=0.3,0.5$, 0.7) and studies of their electrochemical behavior. J. Electrochem. Soc. 2010, 157, A1121-A1130.

56. Armstrong, A.; Robertson, A.; Bruce, P. Structural transformation on cycling layered $\operatorname{Li}\left(\mathrm{Mn}_{1-y} \mathrm{Co}_{y}\right) \mathrm{O}_{2}$ cathode materials. Electrochim. Acta 1999, 45, 285-294. [CrossRef]

57. Ito, A.; Shoda, K.; Sato, Y.; Hatano, M.; Horie, H.; Ohsawa, Y. Direct observation of the partial formation of a framework structure for $\mathrm{Li}$-rich layered cathode material $\mathrm{Li}\left[\mathrm{Ni}_{0.17} \mathrm{Li}_{0.2} \mathrm{Co}_{0.07} \mathrm{Mn}_{0.56}\right] \mathrm{O}_{2}$ upon the first charge and discharge. J. Power Sources 2011, 196, 4785-4790.

58. Myung, S.-T.; Lee, K.-S.; Yoon, C.S.; Sun, Y.-K.; Amine, K.; Yashiro, H. Effect of ALF3 coating on thermal behavior of chemically delithiated $\mathrm{Li}_{0.35}\left[\mathrm{Ni}_{1 / 3} \mathrm{Co}_{1 / 3} \mathrm{Mn}_{1 / 3}\right] \mathrm{O}_{2}$. J. Phys. Chem. C 2010, 114, 4710-4718.

59. Kim, J.-H.; Park, M.-S.; Song, J.-H.; Byun, D.-J.; Kim, Y.-J.; Kim, J.-S. Effect of aluminum fluoride coating on the electrochemical and thermal properties of $0.5 \mathrm{Li}_{2} \mathrm{MnO}_{3} \cdot 0.5 \mathrm{LiNi}_{0.5} \mathrm{Co}_{0.2} \mathrm{Mn}_{0.3} \mathrm{O}_{2}$ composite material. J. Alloy. Compd. 2012, 517, 20-25.

60. Sun, Y.-K.; Cho, S.-W.; Lee, S.-W.; Yoon, C.; Amine, K. ALF3-coating to improve high voltage cycling performance of $\mathrm{Li}\left[\mathrm{Ni}_{1 / 3} \mathrm{Co}_{1 / 3} \mathrm{Mn}_{1 / 3}\right] \mathrm{O}_{2}$ cathode materials for lithium secondary batteries. J. Electrochem. Soc. 2007, 154, A168-A172. [CrossRef]

61. Lee, K.-S.; Myung, S.-T.; Kim, D.-W.; Sun, Y.-K. AlF 3 -coated $\mathrm{LiCoO}_{2}$ and $\mathrm{Li}\left[\mathrm{Ni}_{1 / 3} \mathrm{Co}_{1 / 3} \mathrm{Mn}_{1 / 3}\right] \mathrm{O}_{2}$ blend composite cathode for lithium ion batteries. J. Power Sources 2011, 196, 6974-6977. [CrossRef]

62. Liu, W.; Oh, P.; Liu, X.; Myeong, S.; Cho, W.; Cho, J. Countering voltage decay and capacity fading of lithium-rich cathode material at $60{ }^{\circ} \mathrm{C}$ by hybrid surface protection layers. Adv. Energy Mater. 2015, 5. [CrossRef]

63. Guan, C.; Wang, J. Recent development of advanced electrode materials by atomic layer deposition for electrochemical energy storage. Adv. Sci. 2016, 3. [CrossRef] [PubMed]

64. Choi, M.; Ham, G.; Jin, B.-S.; Lee, S.-M.; Lee, Y.M.; Wang, G.; Kim, H.-S. Ultra-thin Al2O3 coating on the acid-treated $0.3 \mathrm{Li}_{2} \mathrm{MnO}_{3} \cdot 0.7 \mathrm{LiMn}_{0.60} \mathrm{Ni}_{0.25} \mathrm{Co}_{0.15} \mathrm{O}_{2}$ electrode for Li-ion batteries. J. Alloys Compd. 2014, 608, 110-117.

65. Oh, P.; Ko, M.; Myeong, S.; Kim, Y.; Cho, J. A novel surface treatment method and new insight into discharge voltage deterioration for high-performance $0.4 \mathrm{Li}_{2} \mathrm{MnO}_{3}-0.6 \mathrm{LiNi}_{1 / 3} \mathrm{Co}_{1 / 3} \mathrm{Mn}_{1 / 3} \mathrm{O}_{2}$ cathode materials. Adv. Energy Mater. 2014, 4. [CrossRef]

66. Nayak, P.K.; Grinblat, J.; Levi, M.; Markovsky, B.; Aurbach, D. Structural and electrochemical evidence of layered to spinel phase transformation of $\mathrm{Li}$ and $\mathrm{Mn}$ rich layered cathode materials of the formulae $x \mathrm{Li}\left[\mathrm{Li}_{1 / 3} \mathrm{Mn}_{2 / 3}\right] \mathrm{O}_{2} \cdot(1-x) \mathrm{LiMn}_{1 / 3} \mathrm{Ni}_{1 / 3} \mathrm{Co}_{1 / 3} \mathrm{O}_{2}(x=0.2,0.4,0.6)$ upon cycling. J. Electrochem. Soc. 2014, 161, A1534-A1547.

67. Qiao, Q.-Q.; Qin, L.; Li, G.-R.; Wang, Y.-L.; Gao, X.-P. Sn-stabilized Li-rich layered Li( $\left(\mathrm{Li}_{0.17} \mathrm{Ni}_{0.25} \mathrm{Mn}_{0.58}\right) \mathrm{O}_{2}$ oxide as a cathode for advanced lithium-ion batteries. J. Mater. Chem. A 2015, 3, 17627-17634.

68. Wang, D.; Huang, Y.; Huo, Z.; Chen, L. Synthesize and electrochemical characterization of Mg-doped Li-rich layered $\mathrm{Li}\left[\mathrm{Li}_{0.2} \mathrm{Ni}_{0.2} \mathrm{Mn}_{0.6} \mathrm{O}_{2}\right.$ cathode material. Electrochim. Acta 2013, 107, 461-466. 
69. Nayak, P.K.; Grinblat, J.; Levi, M.; Levi, E.; Kim, S.; Choi, J.W.; Aurbach, D. Al doping for mitigating the capacity fading and voltage decay of layered $\mathrm{Li}$ and $\mathrm{Mn}$-rich cathodes for Li-ion batteries. Adv. Energy Mater. 2016. [CrossRef]

70. Nayak, P.K.; Grinblat, J.; Levi, E.; Levi, M.; Markovsky, B.; Aurbach, D. Understanding the influence of Mg doping for the stabilization of capacity and higher discharge voltage of $\mathrm{Li}$ - and $\mathrm{Mn}$-rich cathodes for Li-ion batteries. Phys. Chem. Chem. Phys. 2017, 19, 6142-6152. [CrossRef] [PubMed]

71. Erickson, E.M.; Schipper, F.; Tian, R.; Shin, J.-Y.; Erk, C.; Chesneau, F.F.; Lampert, J.K.; Markovsky, B.; Aurbach, D. Enhanced capacity and lower mean charge voltage of Li-rich cathodes for lithium ion batteries resulting from low-temperature electrochemical activation. RSC Adv. 2017, 7, 7116-7121. [CrossRef]

72. Vu, A.; Qian, Y.; Stein, A. Porous electrode materials for lithium-ion batteries-How to prepare them and what makes them special. Adv. Energy Mater. 2012, 2, 1056-1085. [CrossRef]

73. Yang, X.-Y.; Li, Y.; Lemaire, A.; Yu, J.-G.; Su, B.-L. Hierarchically structured functional materials: Synthesis strategies for multimodal porous networks. Pure Appl. Chem. 2009, 81, 2265-2307. [CrossRef]

74. Zhang, L.; Borong, W.; Ning, L.; Feng, W. Hierarchically porous micro-rod lithium-rich cathode material $\mathrm{Li}_{1.2} \mathrm{Ni}_{0.13} \mathrm{Mn}_{0.54} \mathrm{Co}_{0.13} \mathrm{O}_{2}$ for high performance lithium-ion batteries. Electrochim. Acta 2014, 118, 67-74.

75. Ma, S.; Hou, X.; Li, Y.; Ru, Q.; Hu, S.; Lam, K.-H. Performance and mechanism research of hierarchically structured Li-rich cathode materials for advanced lithium-ion batteries. J. Mater. Sci.. Mater. Electron. 2017, 28, 2705-2715. [CrossRef]

76. Duraisamy, S.; Penki, T.R.; Nookala, M. Hierarchically porous $\mathrm{Li}_{1.2} \mathrm{Mn}_{0.6} \mathrm{Ni}_{0.2} \mathrm{O}_{2}$ as a high capacity and high rate capability positive electrode material. New J. Chem. 2016, 40, 1312-1322.

77. Penki, T.R.; Shanmughasundaram, D.; Jeyaseelan, A.; Subramani, A.; Munichandraiah, N. Polymer template assisted synthesis of porous $\mathrm{Li}_{1.2} \mathrm{Mn}_{0.53} \mathrm{Ni}_{0.13} \mathrm{Co}_{0.13} \mathrm{O}_{2}$ as a high capacity and high rate capability positive electrode material. J. Electrochem. Soc. 2014, 161, A33-A39.

78. Penki, T.R.; Shanmughasundaram, D.; Kishore, B.; Jeyaseelan, A.; Subramani, A.; Munichandraiah, N. Composite of Li-rich $\mathrm{Mn}, \mathrm{Ni}$ and Fe oxides as positive electrode materials for Li-ion battery. J. Electrochem. Soc. 2016, 163, A1493-A1502. [CrossRef]

79. Penki, T.R.; Shanmughasundaram, D.; Munichandraiah, N. Porous lithium rich $\mathrm{Li}_{1.2} \mathrm{Mn}_{0.54} \mathrm{Ni}_{0.22} \mathrm{Fe}_{0.04} \mathrm{O}_{2}$ prepared by microemulsion route as a high capacity and high rate capability positive electrode material. Electrochim. Acta 2014, 143, 152-160.

80. Boutonnet, M.; Kizling, J.; Stenius, P.; Maire, G. The preparation of monodisperse colloidal metal particles from microemulsions. Coll. Surf. 1982, 5, 209-225. [CrossRef]

81. Kleitz, F.; Choi, S.H.; Ryoo, R. Cubic ia 3D large mesoporous silica: Synthesis and replication to platinum nanowires, carbon nanorods and carbon nanotubes. Chem. Commun. 2003, 17, 2136-2137. [CrossRef]

82. Chen, M.; Xiang, X.; Chen, D.; Liao, Y.; Huang, Q.; Li, W. Polyethylene glycol-assisted synthesis of hierarchically porous layered lithium-rich oxide as cathode of lithium ion battery. J. Power Sources 2015, 279, 197-204. [CrossRef]

83. Li, Q.; Li, G.; Fu, C.; Luo, D.; Fan, J.; Li, L. K ${ }^{+}$-doped $\mathrm{Li}_{1.2} \mathrm{Mn}_{0.54} \mathrm{Co}_{0.13} \mathrm{Ni}_{0.13} \mathrm{O}_{2}$ : A novel cathode material with an enhanced cycling stability for lithium-ion batteries. ACS Appl. Mater. Interf. 2014, 6, 10330-10341.

84. Song, B.; Liu, H.; Liu, Z.; Xiao, P.; Lai, M.O.; Lu, L. High rate capability caused by surface cubic spinels in Li-rich layer-structured cathodes for Li-ion batteries. Sci. Rep. 2013, 3, 3094. [CrossRef] [PubMed]

85. Gu, M.; Belharouak, I.; Zheng, J.; Wu, H.; Xiao, J.; Genc, A.; Amine, K.; Thevuthasan, S.; Baer, D.R.; Zhang, J.-G. Formation of the spinel phase in the layered composite cathode used in Li-ion batteries. ACS Nano 2012, 7, 760-767. [CrossRef] [PubMed]

86. Xu, B.; Fell, C.R.; Chi, M.; Meng, Y.S. Identifying surface structural changes in layered Li-excess nickel manganese oxides in high voltage lithium ion batteries: A joint experimental and theoretical study. Energy Environ. Sci. 2011, 4, 2223-2233. [CrossRef]

87. Zheng, J.; Gu, M.; Genc, A.; Xiao, J.; Xu, P.; Chen, X.; Zhu, Z.; Zhao, W.; Pullan, L.; Wang, C. Mitigating voltage fade in cathode materials by improving the atomic level uniformity of elemental distribution. Nano Lett. 2014, 14, 2628-2635. [CrossRef] [PubMed]

88. Zheng, J.; Gu, M.; Xiao, J.; Zuo, P.; Wang, C.; Zhang, J.-G. Corrosion/fragmentation of layered composite cathode and related capacity/voltage fading during cycling process. Nano Lett. 2013, 13, 3824-3830. [CrossRef] [PubMed] 
89. Jiang, Y.; Zhuang, H.; Ma, Q.; Jiao, Z.; Zhang, H.; Liu, R.; Chu, Y.; Zhao, B. Synthesis of porous $\mathrm{Li}_{2} \mathrm{MnO}_{3}-\mathrm{LiNi}_{1 / 3} \mathrm{Co}_{1 / 3} \mathrm{Mn}_{1 / 3} \mathrm{O}_{2}$ nanoplates via colloidal crystal template. J. Mater. Res. 2013, 28, 1505-1511. [CrossRef]

90. Zhang, L.; Jiang, J.; Zhang, C.; Wu, B.; Wu, F. High-rate layered lithium-rich cathode nanomaterials for lithium-ion batteries synthesized with the assist of carbon spheres templates. J. Power Sources 2016, 331, 247-257. [CrossRef]

91. Jiang, Y.; Yang, Z.; Luo, W.; Hu, X.; Huang, Y. Hollow $0.3 \mathrm{Li}_{2} \mathrm{MnO}_{3} \cdot 0.7 \mathrm{LiNi}_{0.5} \mathrm{Mn}_{0.5} \mathrm{O}_{2}$ microspheres as a high-performance cathode material for lithium-ion batteries. Phys. Chem. Chem. Phys. 2013, 15, 2954-2960.

92. Wei, C.; Deng, J.; Xi, L.; Zhou, H.; Wang, Z.; Chung, C.Y.; Yao, Q.; Rao, G. High power $\mathrm{LiMn}_{2} \mathrm{O}_{4}$ hollow microsphere cathode materials for lithium ion batteries. Int. J. Electrochem. Sci. 2013, 8, 6775-6783.

93. Duraisamy, S.; Penki, T.R.; Kishore, B.; Barpanda, P.; Nayak, P.K.; Aurbach, D.; Munichandraiah, N. Porous, hollow $\mathrm{Li}_{1.2} \mathrm{Mn}_{0.53} \mathrm{Ni}_{0.13} \mathrm{Co}_{0.13} \mathrm{O}_{2}$ microspheres as a positive electrode material for Li-ion batteries. J. Solid State Electrochem. 2017, 21, 437-445.

94. Hu, Y.S.; Adelhelm, P.; Smarsly, B.M.; Hore, S.; Antonietti, M.; Maier, J. Synthesis of hierarchically porous carbon monoliths with highly ordered microstructure and their application in rechargeable lithium batteries with high-rate capability. Adv. Funct. Mater. 2007, 17, 1873-1878. [CrossRef]

95. Sinha, N.N.; Shivakumara, C.; Munichandraiah, N. High rate capability of a dual-porosity $\mathrm{LiFePO}_{4} / \mathrm{C}$ composite. ACS Appl. Mater. Interf. 2010, 2, 2031-2038. [CrossRef]

96. Schipper, F.; Dixit, M.; Kovacheva, D.; Talianker, M.; Haik, O.; Grinblat, J.; Erickson, E.M.; Ghanty, C.; Major, D.T.; Markovsky, B.; et al. Stabilizing nickel-rich layered cathode materials by a high-charge cation doping strategy: Zirconium-doped $\mathrm{LiNi}_{0.6} \mathrm{Co}_{0.2} \mathrm{Mn}_{0.2} \mathrm{O}_{2}$. J. Mater. Chem. A 2016, 4, 16073-16084. [CrossRef]

97. Aurbach, D.; Srur-Lavi, O.; Ghanty, C.; Dixit, M.; Haik, O.; Talianker, M.; Grinblat, Y.; Leifer, N.; Lavi, R.; Major, D.T.; et al. Studies of aluminum-doped $\mathrm{LiNi}_{0.5} \mathrm{Co}_{0.2} \mathrm{Mn}_{0.3} \mathrm{O}_{2}$ : Electrochemical behavior, aging, structural transformations, and thermal characteristics. J. Electrochem. Soc. 2015, 162, A1014-A1027.

98. Jin, X.; Xu, Q.; Liu, H.; Yuan, X.; Xia, Y. Excellent rate capability of Mg doped Li[ $\left[\mathrm{Li}_{0.2} \mathrm{Ni}_{0.13} \mathrm{Co}_{0.13} \mathrm{Mn}_{0.54}\right] \mathrm{O}_{2}$ cathode material for lithium-ion battery. Electrochim. Acta 2014, 136, 19-26.

99. Liu, L.; Sun, K.N.; Zhang, N.Q.; Yang, T.Y. Improvement of high-voltage cycling behavior of $\mathrm{Li}\left(\mathrm{Ni}_{1 / 3} \mathrm{Co}_{1 / 3} \mathrm{Mn}_{1 / 3}\right) \mathrm{O}_{2}$ cathodes by $\mathrm{Mg}, \mathrm{Cr}$, and $\mathrm{Al}$ substitution. J. Solid State Electrochem. 2009, 13, 1381-1386. [CrossRef]

100. Liu, D.T.; Wang, Z.X.; Chen, L.Q. Comparison of structure and electrochemistry of Al- and Fe-doped $\mathrm{LiNi}_{1 / 3} \mathrm{Co}_{1 / 3} \mathrm{Mn}_{1 / 3} \mathrm{O}_{2}$. Electrochim. Acta 2006, 51, 4199-4203. [CrossRef]

101. Chen, C.H.; Liu, J.; Stoll, M.E.; Henriksen, G.; Vissers, D.R.; Amine, K. Aluminum-doped lithium nickel cobalt oxide electrodes for high-power lithium-ion batteries. J. Power Sources 2004, 128, 278-285. [CrossRef]

102. Jung, S.-K.; Gwon, H.; Hong, J.; Park, K.-Y.; Seo, D.-H.; Kim, H.; Hyun, J.; Yang, W.; Kang, K. Understanding the degradation mechanisms of $\mathrm{LiNi}_{0.5} \mathrm{Co}_{0.2} \mathrm{Mn}_{0.3} \mathrm{O}_{2}$ cathode material in lithium ion batteries. Adv. Energy Mater. 2014, 4, 1300787-n/a.

103. Shin, D.W.; Bridges, C.A.; Huq, A.; Paranthaman, M.P.; Manthiram, A. Role of cation ordering and surface segregation in high-voltage spinel $\mathrm{LiMn}_{1.5} \mathrm{Ni}_{0.5-x} M_{x} \mathrm{O} 4(M=\mathrm{Cr}, \mathrm{Fe}$, and $\mathrm{Ga})$ cathodes for lithium-ion batteries. Chem. Mater. 2012, 24, 3720-3731.

104. Park, B.C.; Kim, H.B.; Myung, S.T.; Amine, K.; Belharouak, I.; Lee, S.M.; Sun, Y.K. Improvement of structural and electrochemical properties of $\mathrm{AlF}_{3}$-coated $\mathrm{Li}\left[\mathrm{Ni}_{1 / 3} \mathrm{Co}_{1 / 3} \mathrm{Mn}_{1 / 3}\right] \mathrm{O}_{2}$ cathode materials on high voltage region. J. Power Sources 2008, 178, 826-831. [CrossRef]

105. Bak, S.-M.; Hu, E.; Zhou, Y.; Yu, X.; Senanayake, S.D.; Cho, S.-J.; Kim, K.-B.; Chung, K.Y.; Yang, X.-Q.; Nam, K.-W. Structural changes and thermal stability of charged $\mathrm{LiNi}_{x} \mathrm{Mn}_{y} \mathrm{Co}_{z} \mathrm{O}_{2}$ cathode materials studied by combined in situ time-resolved XRD and mass spectroscopy. ACS Appl. Mater. Interf. 2014, 6, 22594-22601. [CrossRef] [PubMed]

106. Ghanty, C.; Markovsky, B.; Erickson, E.M.; Talianker, M.; Haik, O.; Tal-Yossef, Y.; Mor, A.; Aurbach, D.; Lampert, J.; Volkov, A.; et al. $\mathrm{Li}^{+}$-ion extraction/insertion of Ni-rich $\mathrm{Li}_{1+x}\left(\mathrm{Ni}_{y} \mathrm{Co}_{z} \mathrm{Mn}_{z}\right) w \mathrm{O}_{2}(0.005<x<0.03$; $y: z=8: 1, w \approx 1)$ electrodes: Insitu XRD and raman spectroscopy study. ChemElectroChem 2015, 2, 1479-1486.

107. Amalraj, S.F.; Sharon, D.; Talianker, M.; Julien, C.M.; Burlaka, L.; Lavi, R.; Zhecheva, E.; Markovsky, B.; Zinigrad, E.; Kovacheva, D. Study of the nanosized $\mathrm{Li}_{2} \mathrm{MnO}_{3}$ : Electrochemical behavior, structure, magnetic properties, and vibrational modes. Electrochim. Acta 2013, 97, 259-270. [CrossRef] 
108. Chen, Z.; Qin, Y.; Amine, K.; Sun, Y.K. Role of surface coating on cathode materials for lithium-ion batteries. J. Mater. Chem. 2010, 20, 7606-7612. [CrossRef]

109. Li, X.; Liu, J.; Meng, X.; Tang, Y.; Banis, M.N.; Yang, J.; Hu, Y.; Li, R.; Cai, M.; Sun, X. Significant impact on cathode performance of lithium-ion batteries by precisely controlled metal oxide nanocoatings via atomic layer deposition. J. Power Sources 2014, 247, 57-69. [CrossRef]

110. Ghanty, C.; Dahiya, P.P.; Basu, R.N.; Chang, J.-K.; Majumder, S.B. Improvement of the electrochemical characteristics of lithium and manganese rich layered cathode materials: Effect of surface coating. J. Electrochem. Soc. 2015, 162, A1957-A1965. [CrossRef]

111. Chen, Y.; Zhang, Y.; Chen, B.; Wang, Z.; Lu, C. An approach to application for $\mathrm{LiNi}_{0.6} \mathrm{Co}_{0.2} \mathrm{Mn}_{0.2} \mathrm{O}_{2}$ cathode material at high cutoff voltage by $\mathrm{TiO}_{2}$ coating. J. Power Sources 2014, 256, 20-27.

112. Qin, C.; Cao, J.; Chen, J.; Dai, G.; Wu, T.; Chen, Y.; Tang, Y.; Li, A.; Chen, Y. Improvement of electrochemical performance of nickel rich $\mathrm{LiNi}_{0.6} \mathrm{Co}_{0.2} \mathrm{Mn}_{0.2} \mathrm{O}_{2}$ cathode active material by ultrathin $\mathrm{TiO}_{2}$ coating. Dalton Trans. 2016, 45, 9669-9675. [PubMed]

113. Cho, W.; Kim, S.-M.; Song, J.H.; Yim, T.; Woo, S.-G.; Lee, K.-W.; Kim, J.-S.; Kim, Y.-J. Improved electrochemical and thermal properties of nickel rich $\mathrm{LiNi}_{0.6} \mathrm{Co}_{0.2} \mathrm{Mn}_{0.2} \mathrm{O}_{2}$ cathode materials by $\mathrm{SiO}_{2}$ coating. J. Power Sources 2015, 282, 45-50.

(C) 2017 by the authors. Licensee MDPI, Basel, Switzerland. This article is an open access article distributed under the terms and conditions of the Creative Commons Attribution (CC BY) license (http:/ / creativecommons.org/licenses/by/4.0/). 